\title{
Exploring the impact of packaging interactions on quality-of-life among older consumers
}

\section{Author information:}

Nicholas Ford (Corresponding author)

Portsmouth Business School

Richmond Building, Portsmouth Business School, Portsmouth, PO1 3DE 02392844141

nicholas.ford@port.ac.uk

Paul Trott

Portsmouth Business School

Richmond Building, Portsmouth Business School, Portsmouth, PO1 3DE 02392844245

paul.trott@port.ac.uk

Christopher Simms

Portsmouth Business School

Richmond Building, Portsmouth Business School, Portsmouth, PO1 3DE 02392844816

chris.simms@port.ac.uk 


\section{Abstract:}

This paper explores the concept of consumer vulnerability in the context of older consumers' packaging interactions. Consumer vulnerability is viewed as a situational state of powerlessness where marketplace imbalances or harm may occur from consuming marketing messages and/or products (Baker, Gentry and Rittenburg, 2005). The paper draws upon evidence from a series of in-depth interviews and observations with a crosssection of 11 consumers aged between 59 and 85 years concerning their experiences with Fast-Moving Consumer Goods packaging. The findings reveal that changes as a result of the multiple dimensions of ageing can increase older consumers' risk of experiencing vulnerability during packaging interactions. The paper provides new insights to aid firms in empowering older consumers through packaging development, thus reducing vulnerability.

\section{Summary statement of contribution:}

This paper contributes to the scant body of research exploring older consumers' packaging experiences from a multidimensional perspective of ageing. The paper also broadens our understanding of the concept of consumer vulnerability by applying it to a new and pertinent context.

\section{Key words:}

Ageing; consumer vulnerability; packaging; new product development.

\section{Introduction:}

Global populations are ageing. The number of persons aged 60 years and over is 810 million globally, with this figure forecast to increase to more than 2 billion by 2050 (United Nations, 2012). The reasons for this demographic shift are threefold: first, decreasing fertility rates; second, new technologies and better standards of living (amongst various other reasons) leading to improved life expectancies; third, the ageing of the baby-boom generation (Laukkanen et al., 2007; Grougiou and Pettigrew, 2009). While increased lifespans are regarded as one of humanity's greatest achievements (Kirkwood, 2009), population ageing is likely to have profound implications for economies and public services (Rosenweig and Stark, 1997; House of Lords, 2013). For example, Metz and Underwood (2005, p. 88) describe how the "pressure on already hard-pressed social services departments to fund long-term care is going to increase, both because of increased demand and decreased supply' as a result of population ageing. Key to alleviating this pressure is the retention of independent living among older people (Foresight, 2000). Research from the Joseph Rowntree Foundation (JRF, 2005, p.1) found that older people value “'that little bit of help' to 
enable them to retain choice, control and dignity their lives". The JFR (2005) emphasise the importance of low-level support to older people, highlighting the ability of firms to provide products and services which facilitate independent living. The Madrid International Plan of Action (MIPAA, 2002), adopted at the Second World Assembly on Ageing, also emphasises the importance of providing enabling environments, products and services which allow older people to advance their health and well-being.

A variety of products and services have been identified as inhibiting older people's abilities to maintain their independence; from public transport to kitchen interiors and internet banking (Kose 1997; Clarkson et al., 2003; Czaja and Lee, 2007). However, few factors are highlighted as often as difficulties with packaging (Visvabharathy and Rink, 1985; Nayak, 1998; Duizer, Robertson and Han, 2009; Kohlbacher and Herstatt, 2010; Age UK 2012). Market research has found high levels of dissatisfaction with much packaging among consumers at large (BBC, 2004; Which, 2013). In particular, dissatisfaction has been reported amongst older consumers with Fast-Moving Consumer Goods (FMCG) packaging (Voorbij and Steenbekkers, 2002; BBC, 2004; ILC, 2010). Studies show that due to changes in physical capabilities and social circumstances, older people risk suffering embarrassment and anger (Sudbury-Riley, 2014), and even potential illness and serious injury (Hudson and Hartwell, 2002) as a result of difficulties with packaging. For example, Winder et al. (2002) highlight the estimated 67,000 visits made to accident and emergency wards each year in the United Kingdom (UK) due to accidents with packaging. Common causes of such accidents are difficulties opening packaging formats such as glass jars, metal cans, and plastic 'clamshell' packages (Lewis et al., 2007) leading consumers to resort to using sharp objects (e.g. scissors, knives, or other blades) as aids (Caner and Pascal, 2010). Whilst consumers of any age may encounter such difficulties with packaging, changes as a result of the ageing process increase the likelihood of such incidents occurring for older people (Voorbij and Steenbekkers, 2002; Duizer, Robertson and Han, 2009). As such, older consumers may experience feelings of vulnerability as a result of packaging interactions. This is in-keeping with Baker, Gentry and Rittenburg (2005) who view vulnerability not as a permanent state, but as a situational experience that may be encountered as a result of a variety of consumer interactions. Given the number and variety of interactions consumers have with FMCG packaging (Ampureo and Villa, 2006) these products may potentially act as a source of vulnerability in multiple ways. As such, older consumers' interactions across the entire 'packaging journey' (from point-of-sale to disposal) require attention.

Using findings from a series of in-depth interviews, this paper highlights opportunities for firms to empower older people through packaging development and to offer 'that little bit of help' in maintaining their independence. Prior research has shown that some older people 
can experience difficulties opening particular closures as a result of biological ageing (e.g. Yoxall et al., 2007). What remains unclear, however, is how social and psychological ageing impacts on consumer-packaging interactions, and what coping mechanisms older people employ to empower themselves in such situations. The findings of this paper provide preliminary exploratory insights that go towards addressing these questions by building upon the scarce research to explore packaging interactions from a multidimensional perspective of ageing (Sudbury-Riley, 2014). In so doing, the paper contributes to literature by exploring the concept of consumer vulnerability in a new context (Adkins and Ozanne, 2005; Baker, 2006; Adkins and Jae, 2010; Blocker et al., 2013), and investigating skills and coping mechanisms older consumers employ to empower themselves whilst interacting with FMCG across the packaging journey. In order to achieve this, the following research questions are explored:

1. How does ageing impact on consumer-packaging interactions?

2. What coping mechanisms do older people employ to empower themselves when experiencing vulnerability whilst interacting with packaging?

The rest of this paper is organised as follows: firstly, literature into consumer vulnerability, ageing and packaging interactions is explored, followed by an overview of the methodology employed in this study. The findings are then presented and theoretical and managerial implications are discussed. Finally, limitations of the study are identified and areas for future research are recommended.

\section{Literature Review:}

\section{Consumer vulnerability}

Vulnerability has long been explored within the field of Sociology, with studies examining the susceptibility of individuals' to experience physical or psychological harm or distress based on their characteristics and social circumstances (e.g. Brown, Bhrolchain and Harris, 1975; Rowland, 1982; McKee and Vilhjalmsson, 1986). Comparatively, the concept of consumer vulnerability is in its infancy. Discussions regarding the nature of vulnerability within the marketplace developed in the mid-nineteen nineties. Researchers such as Ringold (1995, p. 584) who explored the concept of consumer vulnerability in the context of target marketing for products including cigarettes and alcohol described vulnerable consumers as those who have "diminished capacity to understand the role of advertising, products effects, or both". Later, Smith and Cooper-Martin (1997, p.4) described vulnerable consumers as individuals "who are more susceptible to economic, physical or psychological harm in, or as a result of, 
economic transactions because of characteristics that limit their ability to maximise their utility and well-being".

In their seminal paper Baker, Gentry and Rittenburg (2005) proposed a consumer-driven conceptualisation of vulnerability. They describe how consumer vulnerability can occur when "a consumer is unable to accomplish his or her goals in a consumption situation because of being powerless, out of control, and so forth", thus creating dependence on external factors (e.g. marketers) to create fairness in the marketplace (2005, p.134). The conceptualisation does not categorise particular consumers as vulnerable based on demographics alone; instead, consumer vulnerability can be experienced through combination of individual characteristics (e.g. age, socioeconomic standing), individual states (e.g. mood, life transitions), and external conditions (e.g. logistical elements, discrimination). As such, consumer vulnerability is viewed as situational, rather than a permanent condition. It is posited by Baker, Gentry and Rittenburg (2005) and others (e.g. Commuri and Ekici, 2008) that this situational nature means that through a combination of resources and support provided by marketers and policy makers, consumer vulnerability may be lessened or ameliorated for many people.

Subsequent studies have explored consumer vulnerability in a variety of contexts, ranging from carers in the tourism market place (Hunter-Jones, 2011) and disabled people's use of internet shopping (Elms and Tinson, 2012) to Chinese rural migrants use of financial services (Wang and Tian, 2014). Studies exploring consumer vulnerability among older people in depth are relatively limited. A number of researchers have explored older consumers' susceptibility to fall victim of fraud through telemarketing or other unethical sales tactics (e.g. McGhee, 1983; Lee and Soberon-Ferrer, 1997; Lee and Geistfeld, 1999; Langenderfer and Shimp, 2001; Alves and Wilson, 2008). In their exploration of older consumers' experiences of vulnerability when providing informed consent for medical and clinical services, Griffiths and Harmon (2011) argue that a multidimensional perspective of ageing should be adopted when identifying sources of consumer vulnerability among older people.

\section{Multiple dimensions of ageing}

Within marketing literature, the 'senior market' has long been regarded as a heterogeneous segment (e.g. Leventhal, 1997; Smizigin and Carrigan, 2010; Sudbury-Riley, Kohlbacher and Hofmeister, 2012; East, Uncles and Lomax, 2014). This diversity is attributed to the multidimensionality of the ageing process, whereby individuals age in different ways and at 
different rates. Commonly, ageing has been considered as consisting of biological, social and psychological effects (e.g. Ahmad, 2002; Bond et al., 2007; Hooyman and Kiyak, 2008;

Young, Frick and Phelan, 2009; Moschis, Mosteller and Fatt , 2011). Table 1 presents definitions for of each these dimensions from Ahmad's (2002) study exploring the characteristics of older consumers in the UK. 
Table 1 The multiple dimensions of the ageing process (including quotes from Ahmad, 2002).

\begin{tabular}{|l|l|}
\hline Dimension of ageing & Definition \\
\hline Biological ageing & $\begin{array}{l}\text { "A process of change to a person's cells and tissues. These changes cause a } \\
\text { deterioration of individuals' biological system, which, in turn, makes them susceptible } \\
\text { to illness and alters their functional capacity, for example to listen, to see, to walk and } \\
\text { to travel”. }\end{array}$ \\
\hline Psychological ageing & $\begin{array}{l}\text { "Focuses on mental abilities and sees changes in a person's ability to think and } \\
\text { reason. Psychological ageing measures the change in cognition and personality of } \\
\text { individuals; for example, in processing information, understanding advertising }\end{array}$ \\
\hline Social ageing & $\begin{array}{l}\text { "Sees changes in individuals' social relationships within their social groups. } \\
\text { Sociological ageing measures individuals' ability to play various roles throughout their } \\
\text { life such as heads of family, grandfathers or leaders of consumer groups". }\end{array}$ \\
\hline
\end{tabular}


Despite the multidimensionality of the ageing process being widely understood and accepted in marketing studies, other areas of management literature are said to view ageing too simplistically, often basing their understanding on chronological age alone (Sudbury and Simcock, 2009). As a result, many studies limit their understanding of ageing to that of senescence. Derived from the Latin senex, meaning old man or older age, senescence is defined by Campisi and di Fagagna (2007, p. 730 ) as "deteriorative processes that follow development and maturation". While the effects of senescence are universally experienced to varying degrees, to view ageing only through the lens of senescence overlooks the other dimensions which comprise the ageing process. Human beings age in complex ways, affected as much by social and psychological processes as biological ones (Moen, Dempster-McClain and Williams Jr., 1992). Therefore, viewing ageing as a multidimensional process offers wider meaning and implications than when seen merely through chronological age (Ahmad, 2002). Considering the multiple dimensions of ageing is also likely to offer greater insights into an individual's cognitive age; a construct regarded as providing a more accurate method for understanding segmenting the senior market that chronological age (Moschis and Mathur, 2005; Sudbury and Simcock, 2009). The result of a myopic chronologic-centric view is a lack of understanding about older consumers (Gunter, 1998; Thornton, 2002; Mumel and Prodnik, 2005) and, in turn, the development of products which are unsuitable for many older people's needs (Lunsford and Burnett, 1992; Hare, Kirk and Lang, 1999; Lyon, Kinney and Colquhoun, 2002; Pak and Kambil, 2006; Goddard and Nicolle, 2012).

In the case of food consumption, Wills et al. (2013) found ageing to affect individuals' relationships and interactions with food products. It was observed how kitchen practices (and interactions with food) shifted for many older people as their physiology and social circumstances changed (e.g. increased frailty, bereavement, living alone) (Dickinson et al., 2014; Schroder-Butterfill and Marianti, 2006). In circumstances such as these where individuals experience greater isolation, increased reliance is placed on sensory logics to inspect food, thus leading to increased risk of foodborne illness. This risk is increased for those individuals experiencing biological and psychological changes which impact on their abilities to decipher information from packaging. As such, older people are seen as more likely to experience vulnerability when consuming food products through increased exposure to foodborne illness (Dickinson et al., 2014). Other studies have noted changes in food consumption as a result of aspects of biological ageing. For example, a reduction in consumption is noted among older people (Hughes et al., 2004; Simpson et al., 2005). Known as the 'anorexia of ageing', this reduction is partly attributed to decreasing abilities to taste and smell (Popper and Kroll, 2003; Dean et al., 2009). Changes to circumstances 
through social ageing (e.g. becoming an empty nester) may exacerbate these problems further. den Uijl et al. (2014) adopt a socio-emotional selectivity theory perspective to suggest that many older people place greater emotional significance on food consumption and meal experiences. As a result, being unable to derive similar levels of enjoyment from consumption activities may negatively affect some older people's quality-of-life as they are unable to satisfactorily achieve their consumption goals. Given the integral role of packaging in FMCG products delivering value to consumers (Simms and Trott, 2010), this suggests that packaging may be a significant factor in the value older people derive from consumption experiences. The following subsection will reflect on literature exploring older people's packaging experiences in relation to the multiple functions of packaging.

\section{Older consumers' packaging experiences}

In order to understand consumers' packaging needs, interactions across the packaging journey require consideration. Deasy (2000, cited by Ampureo and Vila, 2006, p.102) illustrates the variety of consumer-packaging interactions across the packaging journey, highlighting the following stages: (1) Point of sale; (2) transporting the product home; (3) home storage; (4) opening; (5) serving the product for consumption; (6) reclosing or putting away; and (7) disposal. However, research into older consumer's interactions with FMCG packaging is relatively limited. The stages of point-of-sale (PoS) and opening have been afforded greatest attention.

A number of studies have discussed the impact packaging at PoS, often exploring the effects of alternative graphical design elements on consumer decision making (e.g. Nancarrow, Wright and Brace, 1998; van den Berg-Weitzel and van de Laar, 2001; Silayoi and Speece, 2004). In their study, Piqueras-Fiszman et al. (2011) describe how ageing may affect product perceptions based on packaging colours, symbology, typography and materials. These factors which form the basis of consumer product perceptions may be influenced by mental associations formed as a result of traditions and events experienced across the life course. For example, in her exploration of older people's perceptions of pharmaceuticals packaging, Kauppinen-Räisänen (2011) describes how older people value the colour of a painkiller over the manufacturer of the pharmaceutical when compared with younger consumers. Other studies highlight how age-related changes to eyesight can detract from individual's abilities to decipher product information from packaging (e.g. Chavalkul et al., 2011). In the case of pharmaceutical products, difficulties deciphering product/dosage information may place consumers in immediate harm, thus contributing to potential vulnerability. Regarding FMCG products, similar experiences may be had with 
cooking instructions for food products or usage guidelines for household products featuring hazardous chemicals. For those older people experiencing impairment to their abilities to process verbal information experiences of vulnerability may be increased due to the greater dependence placed on packaging as a source of information (Paddison and Olsen, 2008). Furthermore, Duizer et al. (2009) found that many older people believe that eyesight problems contributed to difficulties they experience opening products as they are less confident in how to approach opening mechanisms. Whilst providing valuable insights, these studies only capture a fraction of the interactions between consumers and packaging. As Devendorf and Lewis (2010, p. 2) note: "While point of sale is an important instance of consumer-product packaging interaction, it is only one of many times when a consumer will interface with the product package". As Duizer et al., (2009) suggest, issues encountered at one stage of the packaging journey may also impact on interactions at latter stages (e.g. opening), highlighting the iterative nature of packaging interactions.

Research from the field of ergonomics has explored older consumers' abilities to operate particular packaging closures (e.g. Lewis et al., 2007; Yoxall, Luxmoore and Rowson 2008). These studies provide insights into the effects of biological ageing on particular packaging interactions, suggesting that changes to hand strength and dexterity as individuals age reduce their ability to safely open a variety of FMCG products. These difficulties can be exacerbated by other biological changes that naturally affect the majority of people in laterlife, such as changes to eyesight (McGraw and Drennan, 2004). Such difficulties are befitting of Adkins and Jae's (2008, p. 95) conceptualisation of consumer vulnerability which entails "a state of powerlessness manifesting when individual characteristics and fluctuating consumer states combine with structural and other socioenvironmental elements to produce conditions where marketplace imbalances or harm may occur as a result of consuming marketing messages and/or products". The loss of control some older consumers experience when engaging with particular closure types may, therefore, lead to feelings of consumer vulnerability. Whilst providing valuable insights and implications for packaging designers, ergonomics studies also tend to focus on isolated incidents within the broader packaging journey. As such, focusing only on the consumer's the initial opening of the product also offers limited scope to understand packaging experiences and the potential effects iterative effects of difficulties encountered at multiple stages. Furthermore, focusing on isolated stages of the packaging journey often leads to examination of individual packaging functions. This offers a limited view of packaging. As Robertson (2013) describes, packaging performs a number of functions. These include protecting and containing products, communicating logistical information and marketing communications messages, and providing various user conveniences such as re-sealable closures and alternative 
apportionment options. As such, there is a need to consider how ageing may affect consumer-packaging interactions across the packaging journey in relation to multiple functions of packaging.

Research exploring consumer-packaging interactions from a multidimensional perspective on ageing is comparatively scarce. In her study exploring older consumers' packaging experiences Sudbury-Riley (2014) describes how the effects of packaging related stresses on an individual's self-concept also have implications for social ageing. Linking difficulties with packaging to the theory of social breakdown syndrome (Kuypers and Bengston, 1973; Bengston, Putney and Johnston, 2005), Sudbury-Riley (2014) describes a "vicious circle where negative aspects of ageing create a vulnerability to and dependence on sources of external labelling". In the case of packaging interactions, feelings of uselessness and inadequacy due to physical difficulties with packaging can become a self-fulfilling prophecy where older consumers assume a role which identifies with their negative feelings (SudburyRiley, 2014).

\section{Daily hassles, mastery and quality-of-life}

The concept of self-efficacy has been linked with quality-of-life (QoL) and avoidance of social breakdown among older people (Bowling, 2005). Self-efficacy is said to aid older people in coping with stresses which they experience as a result of age-related changes (Bowling et al., 2007), thus contributing to QoL. Mastery has been highlighted as a defence against stressful consequences (Pearlin and Schooler, 1978; Lazarus and Folkham, 1984). According to Burger (1989, p. 246), mastery is the "perceived ability to significantly alter events". Similarly, Ben-Zur (2002, p. 359) describes mastery as "whether one regards life occurrences as being under personal control or under fatalistic control'. Individuals who exhibit high levels of mastery are more likely to respond to stresses with active coping mechanisms such as problem-focussed strategies, rather than following avoidance/disengagement strategies (Ben-Zur, 1999; Ben-Zur, 2002). While mastery has been associated with positive coping mechanisms to major life events such as recovering from heart surgery (Fitzgerald et al., 1993), other research has linked mastery with 'daily hassles' (e.g. Pearlin and Schooler, 1978; Jeon, Dunkle and Roberts, 2006). Kanner et al. (1981, p. 3) define daily hassles as "...the irritating, frustrating, distressing demands that to some degree characterize every transactions with the environment". Daily hassles have been examined in the contexts of the workplace (Zohar, 1999) and in the lives of university students (Bouteyre, Marion and Bernaud, 2007), but also include other fortuitous occurrences such as bad weather, arguments, disappointments, and family concerns 
(Kanner et al., 1981). The concept of daily hassles has been linked to vulnerability (e.g. Almeida, 2005); however, little research has considered daily hassles in relation to the conditions and marketplace interactions which may lead to consumer vulnerability. Lay and Safdar (2003, p. 3) highlight the accumulative nature of daily hassles, describing their "substantial influence on psychological distress, even when compared to major life events". A number of other studies have linked stress as a result of daily hassles with both a decline in physical and mental health among older people (e.g. Fernandez and Jeanie, 1996; Lau, Wai and Shiu, 1996; Kraaij, Arensman and Spinhoven, 2002; Sher, 2004). To date, no studies have explicitly explored packaging interactions from a daily hassles perspective. However, issues such as difficulties with opening products and the frequency with which consumers engage with FMCG products mean that negative experiences with packaging are in-keeping with the concept of daily hassles. Whilst specific segments of consumers should not be considered as predisposed to experience vulnerability (Wratten, 1995; Commuri and Ekici, 2008), changes as a result of the ageing process may lead older consumers to encounter a greater variety of stresses when interacting with packaging (Duizer, Robertson and Han, 2009). The multifaceted nature of consumer-packaging interactions also increases the potential of encountering vulnerability when engaging with FMCG products. The iterative accumulation of such stresses may therefore constitute a unique form of consumer vulnerability for older consumers; one which is less conspicuous, but as impactful as the forms of consumer vulnerability examined in prior studies. Lapierre et al. (2012, p.244) also suggest that the variety and frequency of daily hassles often increase for older people following a major life event, stating that "It seems the challenge of adaptation posed by a major life event may be found more in the changes in daily living that accompany this event". Given the variety of life transitions many older people experience through social ageing (e.g. entering retirement, becoming an empty-nester, or suffering bereavement) (Silvers, 1997; Sherman et al., 2001; Perry and Wolburg, 2011), this may increase their susceptibility for encountering consumer vulnerability when engaging with FMCG products. However, in his exploration of consumer vulnerability among older people, Clough (2015) describes how independence in later life is not absolute. Dependent on the context, older people may perceive themselves as independent, whether they themselves are performing a task or have someone do it for them (Clough, 2015, p. 133). As such, difficulties in daily life (such as problems with packaging) may not lead to experiences of vulnerability if coping mechanisms can be employed to enable older people to maintain a sense of control of their marketplace interactions.

Based on the above, there is a need to not only explore the effects of biological ageing upon packaging interactions, but to also consider the implications for psychological ageing in 
terms of coping mechanisms and the impact upon individuals' self-concepts. This consideration should also take into account the effects of social ageing and the impact such changes can have on an individual's QoL and susceptibility to experience consumer vulnerability.

\section{Methodology:}

\section{Semi-structured interviews}

The methodology employed in this research involved semi-structured in-depth interviews and observations with older consumers exploring their experiences with and opinions on packaging. Gubrium and Sankar (1994, p. 123), describe in-depth interviewing as being ideal "when the goal is to collect detailed, richly textured, person-centered information". Semi-structured interviews were employed as they provide sufficient flexibility to approach participants differently (Noor, 2008, p. 1604) and to allow for further exploration into new and potentially fruitful points as they arise (Nag, Corley and Gioia, 2007).

Participants were interviewed typically for an hour to an hour and a half. According to Perakyla and Ruusuvuori (2011, p. 529) the use of interviews allows researchers to "reach areas of reality that would otherwise remain inaccessible such as people's subjective experiences and attitudes". As such, interviews permit researchers to go beyond asking "'What?" or "how many?' questions, to ask questions of "how and why things happen" (Miles and Huberman, 1994, p. 10). Interviews were therefore an appropriate method for exploring older consumers' experiences with packaging and for the provision of rich, contextual data that was sought. The questions posed were designed to stimulate discussions regarding changes to lifestyles and consumption, as well as physiological changes that have come as a result of the ageing process. Initially, questions regarding changes to participants' shopping habits were explored. The questioning then narrowed to explore how participants' FMCG consumption had changed, and then focused specifically on experiences with and opinions on packaging. These questions related to the packaging of all categories of FMCG products. Whilst consumers may interact more frequently with certain categories of products (for example, food and drink products compared with household cleaners), it is possible that the packaging of any product may lead to experiences of vulnerability. The concept of consumer vulnerability was not referred to in the questioning. This reduced the likelihood of remarks being framed by the researchers, thus enhancing the validity of the data (McCracken, 1988; Baker, 2006). 


\section{Participant observations}

Participant observations were employed to support and consolidate the data gathered during the interviews. According to Robson (2002, p. 189), researchers that immerse themselves in realistic research settings are able generate data that is "superior to retrospective accounts", thus helping to overcome difficulties some participants may have when attempting to "verbalize and reconstruct a version of what happened". Observations also permit a greater wealth of detail than other data collection techniques and can increase the soundness of interpretation (Becker, 1958). As Baker, Gentry and Rittenburg (2005) describe, in order to distinguish between perceived and actual vulnerability researchers must listen to and observe the experiences of the consumer. Similar approaches have been adopted in a number of studies exploring both consumer vulnerability (e.g. Baker, 2006; Hunter-Jones, 2011; Jafari et al., 2013; Wang and Tian, 2013) and older consumers' interactions with FMCG products and kitchen practices (e.g. Wills et al., 2013; Dickinson et al., 2014; Wills et al., 2015). This approach allowed these researchers to "observe the many nuances and contingencies of human behaviour as they become manifest in a 'natural' setting" (Marvasti, 2014, p.355).

The researcher assumed the role of a 'peripheral member' within the observer-observed interconnection (Adler and Adler, 1987), meaning they had marginal involvement in what was being observed (Marvasti, 2014, p. 356). The researcher observed and conversed with participants but avoided offering assistance or personal opinions in order to minimise impact upon the participant's behaviour. Observations followed an unstructured approach. Most observations took place in consumers' kitchens as this is where the majority of interactions with packaging take place. However, as Deasy (2000, cited by Ampuero and Vila, 2006) identifies, consumer-packaging interactions begin in the store, not the home. As such, two modes of observations were utilised: one featuring in-store interactions only, another also capturing shopping trips starting from the home.

The researcher met with the participants at their homes at a convenient time when they would typically go shopping and then accompanied them to the store using their usual mode of transport. This allowed for the generation of additional insights to combine with and support data gathered from interviews (including interactions during the process of transporting and storing products, thus providing a more holistic overview of the 'packaging journey'). In the cases where the researcher only conducted observations in participant's homes, these generally took place at the end of interviews or occasionally during. These observations typically focused on participants demonstrating issues they encounter with packaging and methods for overcoming these issues. Engaging with and referring to 
particular products aided participants in recalling additional experiences with packaging which they had overlooked during the interview process. During observations in the home the researchers recorded the discussions with a digital Dictaphone and through jotted notes.

During observations in-store, mental and jotted notes were made which were then later elaborated on into full field notes which included information on specific interactions, locations, and other events (Bryman and Bell, 2007). Photographs were also used to enrich the data and aid the analysis process by providing what Flick (2009, p.p 241) describes as "detailed recordings of facts as well as... a more comprehensive and holistic presentation of lifestyles and conditions". The digital recording of the time and date when the photographs were taken aided the cataloguing of data and provided visual details for triangulation with the other data sources (Belk, Fischer and Kozinets, 2013).

\section{Sample}

In light of the exploratory nature of the research, a purposive non-representative sample was used. See Table 2 for interviewee details. Participants; chronological ages ranged from 59 to 85. The lower age bracket of $55+$ was adopted as this is the definition employed in many marketing studies exploring older consumers' behaviour (e.g. Moschis, 1992; Carrigan et al., 2004; Laukkanen et al., 2007; Myers and Lumbers, 2008; Cowart and Darke, 2014). The breadth of chronological ages (59-82) within the sample has certain limitations regarding the extent to which we can discuss our sample as one homogenous group (older people). To alleviate this issue, where possible, we have endeavoured to explore the patterns in the data between younger and older participants, in addition to exploring the broader themes that emerged across the data. Additional eligibility criteria included participants living independently in order to ensure regular interactions were had with packaging. For those participants living in multiple occupancy (either with children and/or a partner), the influence these individuals may have on the participants' packaging interactions (e.g. being able to offer assistance) was incorporated into the open questioning and data analysis. 
Table 2: Participant Details for Part One Interviews and Observations

\begin{tabular}{|c|c|c|c|}
\hline Interviewee Pseudonym & Age (years) & Gender & $\begin{array}{l}\text { Total number of People } \\
\text { in Household and } \\
\text { Details of additional } \\
\text { Occupants }\end{array}$ \\
\hline Maude & 82 & Female & 1 \\
\hline Bill & 85 & Male & 2 \\
\hline June & 61 & Female & 3 \\
\hline Carol & 77 & Female & 1 \\
\hline Philippa & 73 & Female & 1 \\
\hline Elizabeth & 72 & Female & 1 \\
\hline Janet & 76 & Female & 1 \\
\hline Yvonne & 81 & Female & 1 \\
\hline Michael & 59 & Male & 2 \\
\hline $\mathrm{Jim}$ & 63 & Male & $\begin{array}{l}4 \\
\text { (Wife, Daughter, and Son- } \\
\text { in-law) }\end{array}$ \\
\hline Sue & 62 & Female & $\begin{array}{l}4 \\
\text { (Husband, Daughter, and } \\
\text { Son-in-law) }\end{array}$ \\
\hline
\end{tabular}




\section{Data analysis}

In order to ensure a rigorous approach was adopted during data analysis, the researchers drew upon the naturalistic enquiry guidelines of Lincoln and Guba (1985), and adhered to the process of constant comparison (Glaser and Strauss, 1967). Patterns and apparent contradictions/exceptions within the data were identified using analytic induction. Identifying deviant findings with the data provided the researchers with alternative constructs to explore, thus contributing to the theoretical development. Discussions during observations were subjected to the same data analysis process, and were also supported by reference to notes. 


\section{Findings:}

The following subsections will detail packaging interactions across the packaging journey. Using Deasy's (2000, cited by Ampuero and Vila, 2006) 'Positioning Transmission Points' framework as a structure, key themes that emerged at each stage of this process are detailed below. Appendix One presents a table with further illustrative quotes the study. 
Figure. 1 Deasy's (2000, cited by Ampuero and Vila, 2006) Positioning Transmission Points (Adapted by Author)

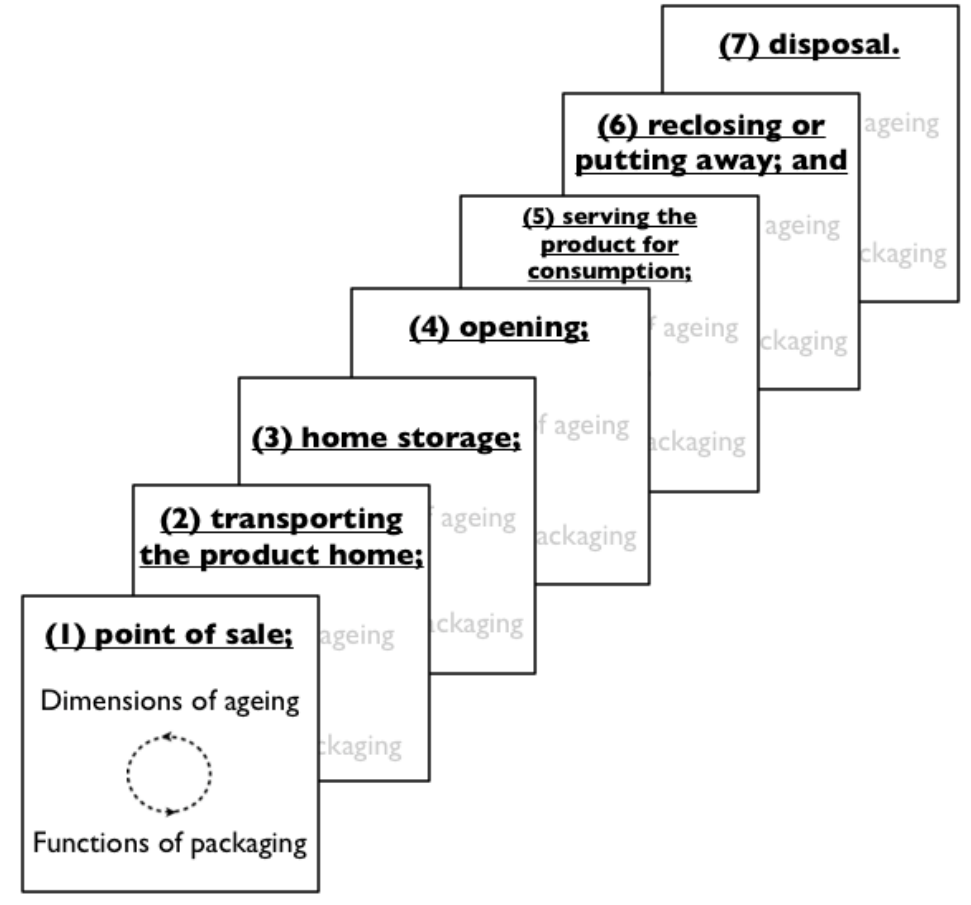




\section{Point of sale}

As all participants were living independently and shopping for themselves, consumerpackaging interactions began in-store, often when locating a product on the shelf. A key issue for several participants related to the function of communication; specifically, the provision of nutritional information and cooking instructions. Participants expressed dissatisfaction with font sizes used on a variety of packs. These issues were found to not only impact upon consumer-packaging interactions, but also to negatively affect shopping experiences:

"The fonts are far too small. I can't read it when I'm in the shop without my glasses. It's an inconvenience. When you're in the shop you don't want to be fumbling around in your handbag for your glasses, people will think you're shoplifting" - June (61).

These issues support Sudbury-Riley's (2014) assertion that difficulties with packaging can lead to experiences of embarrassment for older consumers. Other participants believed agerelated changes to their vision increased their susceptibility to being misled by unclear and deceptive imagery on packaging:

"There have been occasions when l've not had my glasses with me that l've been caught out. The ready-made meals are particularly bad. Some of the pictures look nothing like what you get in the pack. You're not sure what you're buying, but I never want to ask anyone for help with something so embarrassing" (Jim, 63).

Such negative experiences are comparable with the powerlessness described by Broderick et al., (2011, p. 5) as resulting from "perceived frailty of social identity" leading to a loss of consumer confidence. This loss of confidence was found to develop into feelings of frustration and irritation with packs which participants felt included large areas of 'open' and 'wasted' space. An example of such a pack was Sue's cereal box (see Figure 2) that she felt dedicated too much space to decoration/imagery at the expense of valuable product information. 
Figure 2: Sue's (62) Cereal Box with 'Wasted' and 'Open' Space

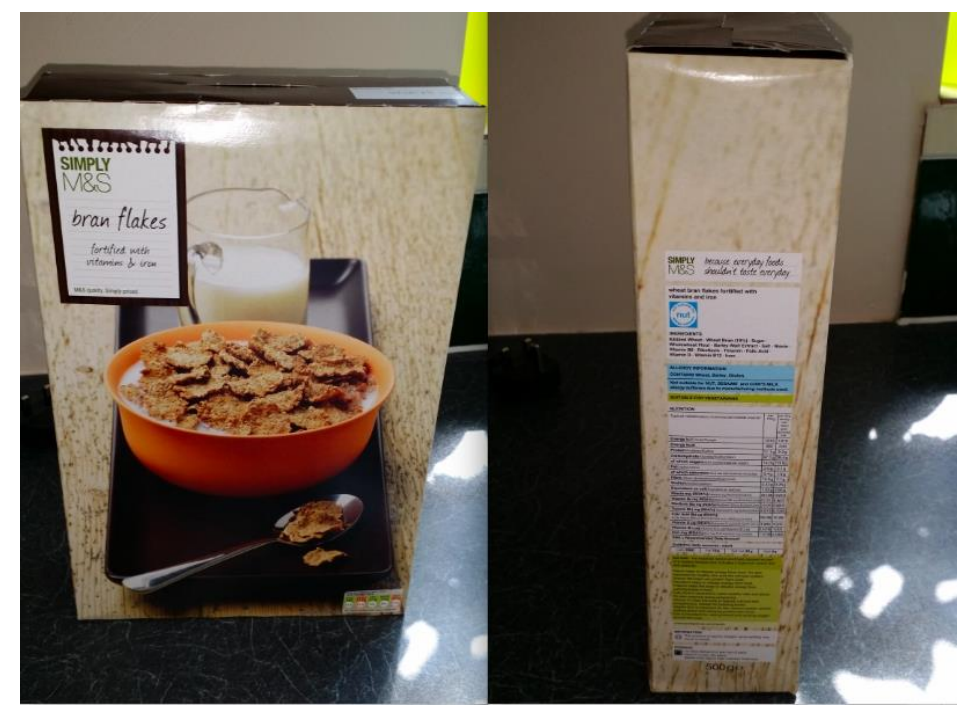


A specific user convenience a number of participants expressed a preference for at PoS was transparent packaging. Participants described the desire to inspect products in-store, expressing cynicism towards marketing communications images, including those on packaging. For example, Sue described the frustration of opening products (in this case a boxed cake) which bear little resemblance to the image depicted on the pack.

"The picture of the front of the box suggests that it will fill a plate, but when you get it home it'll fit on a saucer almost. You think, 'I've been had here'. That makes me cross" - Sue (62).

These feelings further contributed to the desire for transparent packaging or methods of shopping which allowed for prior inspection of products. For example, consumers such as Bill and Maude commented on their use of delicatessen facilities. Use of these facilities is partly attributed to knowledge of marketing communications techniques gathered over the life-course:

"When you get to my age you know the tricks these companies try to pull. After so many purchases you cotton on to the fact that the food isn't going to look like the picture on the pack. You'll be disappointed every time if you think that way. Using the deli counter means I can actually see what l'm getting" Bill (86).

Purchasing products from the delicatessen counter offered a means of inspecting products before purchase, thus instilling a sense of trust in the product and control over the consumption process. Participants' mistrust of packaging imagery is befitting of Adkins and Jae's (2010) description of consumer vulnerability as marketplace imbalances resulting from the consumption of marketing messages. This mistrust is also illustrative of Wratten's (1995, p. 17) description of vulnerability as insecurity experienced as a result of exposure to different forms of risk and stress; in this case, the risk being the anticipated quality of products concealed by packaging. These findings highlight forms of potential vulnerability that older consumers may experience when engaging with packaging at PoS concerning fair marketplace exchanges.

Whilst discussing packaging experiences, a number of participants made reference to their shopping experiences more generally. Several older participants described shopping in larger stores as a 'chore' due to changes to their physical capabilities as a result of biological ageing. For some, the physical exertion required during shopping trips reinforced negative perceptions of older age: 
"...these last three years, going around the big shops is a bit much. It's something I have to do, rather than something I enjoy doing anymore... I haven't quite got the stamina for it. It's very annoying when you can't do something anymore that you used to like doing" - Maude (82).

In order to experience the same sense of enjoyment previously gained through shopping in larger stores, several participants included Elizabeth, Philippa and Carol described visits to smaller convenience stores on an almost daily basis. Regular shopping as a means of social interaction emerged as a prominent theme:

"Shopping is a social thing; it gets you out of the house. When you go to a smaller shop it's less stressful. You can have a look around, see people you know...enjoy it a bit more" - Carol (77).

For people like Carol, these changes in shopping habits were in response to changes of biological ageing, but also changes in social ageing. For example, individuals who were empty nesters or had suffered bereavement used shopping trips as a means of maintaining social engagement:

"For me and my friends going out grocery shopping is about much more than just getting food in for the week. Quite a few of them are like me and have lost their partners, so getting to see each other out at the shops is lovely. Even if it is just at The Co-op!' (Elizabeth, 72).

Elizabeth's narrative reflects the findings of prior studies exploring shopping as a form of socialisation in later life (e.g. Forman and Sriram, 1991; Balazs, 1994; Kang and Ridgway, 1996; Kim et al., 2005; Lim and Kim, 2011). These examples provide further evidence to the body of literature questioning the accuracy of disengagement theory (e.g. Bengston, Putney and Johnston, 2005; Bowling, 2005). Rather than withdrawing from society, older people adapt their activities and behaviours in order to avoid situational vulnerability maintain their desired QoL.

In addition to the physical exertion required to navigate supermarkets, several participants also made reference to the wealth of products available. Rather than improving their shopping experiences, the amount of choice was considered overwhelming and of detriment. These feelings are analogous to the concept of choice paradox:

"I find the shelves quite terrifying now. There's just too much" - Elizabeth (72). 
Contrary to the assertion that increased choice enhances shopping experiences, Elizabeth regarded the variety of products available at larger supermarkets as 'excessive'. During observations in store, having spent several minutes trying to locate her preferred tin of soup, Elizabeth remarked that she felt 'at the mercy' of the retailer, implying a loss of control over her shopping experiences. This is in-keeping with Shankar, Cherrier and Canniford's (2006) conceptualisation of choice paradox, which asserts that increased choice in supermarket environments can be de-motivating for consumers; "restricting choice within the supermarket environment could actually increase turnover, make shoppers more content with the shopping experience and potentially more loyal as a result" (2006, p. 1022).

Other participants described the value of distinctive packaging to aid them when locating items in busy retail spaces:

"In some of the shops there's far too much to choose from. It makes shopping far more stressful than it should be. There are certain things that really stand out from the rest though. Like the ' $\mathrm{J} 2 \mathrm{O}$ ' bottles. I can spot them from a mile off because they look so different to the other drinks. You feel a bit more in control finding something like that' (Janet, 76).

These insights highlight the importance of packaging's role in differentiating products on busy and fragmented supermarket shelves (Silayoi and Speece, 2004; Becker et al., 2011). Furthermore, Janet's experiences also reveal the potential for packaging to instil a greater sense of control over shopping experiences by facilitating easier identification of products. For those older consumers experiencing choice paradox in supermarket environments, this greater sense of control may reduce susceptibility to consumer vulnerability at this stage of the packaging journey.

\section{Transporting the product home}

Product size and weight were found to influence purchasing decisions. Where possible, a number of consumers selected smaller and lighter packages (made possible by use of lighter packaging materials and reduced apportionment) which better suited their physiological requirements that had changed as a result of biological ageing. For example, Philippa's narration reveals how alternative (lighter) packaging materials help alleviate the increased physical strain she experiences when shopping and transporting goods home: 
"I used to always buy my cat food in a tin, then I discovered those pouch packs. Because shopping's much harder than it used to be, finding stuff like that it great as it's so much lighter for me to carry home. The cat doesn't care where it's comes from and it's easier for me" (Philippa, 73).

However, in some cases, finding smaller alternatives was not possible. This meant that difficulties encountered in-store with handling products continued during the process of transporting products home. Participants such as Yvonne described her frustration at changes as a result of biological ageing impacting upon her ability to transport her shopping home:

"I used to go to Commercial Road and come back with 10lbs of potatoes, things like that. I get so cross that I can't do that anymore. The spirit is willing, but the body won't allow it' - (Yvonne, 81).

Yvonne's (81) feelings reflect the continuation of difficulties in-store to the process of transporting products to her home caused by unsuitable apportionment. The negative impact of physiological issues encountered in store on an individual's self-concept was further reinforced by the onerous and physically exerting process of transporting products home. For participants using public transport or shopping by foot, this negative reinforcement was particularly acute. As a result, those without access to a car (approximately a quarter of participants) would rarely visit larger supermarkets. Instead of visiting supermarkets, many participants would take daily trips to convenience stores to purchase smaller amounts of shopping. For others, discussions regarding transporting products home evoked greater awareness of ageing. For example, Sue made predictions as to how her shopping habits may change as she aged:

"I'm beginning to think sometimes, it feels like my shopping is getting heavier pushing it around, maybe I should do online shopping. I know that I'll probably have to come round to it" - Sue (62).

Whilst Sue anticipated changes to her shopping habits due to physiological changes she was beginning to experience, other older participants such as Philippa already had adjusted their habits in order to avoid experiences of vulnerability:

"The size of things is very frustrating now, not just because it's more than I need, but because it's so hard to get home. Ever since I fell a couple of winters ago and did my hip in, I always make sure to just buy a few bits now. It was my own stupid fault carrying too much; I should have known my limits at my age" (Philippa, 73). 
Clearly, these insights suggest that firms may be able to add value for older consumers by developing packaging which is smaller and lighter, or through the inclusion of handles on particularly onerous products. These findings also offer further insights into the impact of ageing and consumer-packaging interactions on shopping habits and experiences. For example, firms may able to reduce the risk of experiencing consumer vulnerability through consumer education initiatives to guide shopping habits; highlighting the benefits of shopping for larger, more onerous product online, while visiting bricks and mortar stores for fresh goods (Oumlil and Williams, 2000). In addition to Sue who perceived the benefits of online shopping and anticipated making greater use of these services in the future, other participants such as Michael (59), Jim (63), and June (61) engaged in online shopping. This is in-keeping with the findings of a number of studies which report high levels of internet usage and positive attitudes towards technology among older people (Vuori and HolmlundRytkonen, 2005; Laukkanen, Sinkkonen and Laukkanen, 2007; Niemelä-Nyrhinen, 2007; ONS, 2010). In particular, members of the baby-boom cohort exhibit acceptance of internet shopping (Mintel, 2008). This suggests that as the baby-boom cohort ages that firms may benefit from further promoting the benefits of online shopping with regards to maintaining independence by offering a more convenient method of purchasing particular products. When combined with existing services such as free bus services (currently offered by particular retailers at select stores), firms may be able to significantly reduce the risk of older consumers experiencing vulnerability at this stage of the packaging journey.

\section{Home storage}

For a number of participants, physiological difficulties encountered whilst transporting products proved unrelenting and continued during home storage when placing and retrieving items. For those participants living alone, these issues were particularly pertinent. For example, participants who were empty nesters and/or widows had reduced access to assistance with regards to storing their shopping. Unlike issues of openability, for which some participants were able to employ problem-based coping strategies (see the following subsection); difficulties storing products were harder to counter. For example, whilst participants such as Maude were able to overcome particular problems around her kitchen (such as having mirrors installed in the ceiling of her cabinets to aid her in locating items), she perceived the physical exertion involved in storing larger more onerous FMCG products as being impossible to avoid. This demonstrates both the importance of considering packaging interactions in the context of the packaging journey and how difficulties with packaging can lead to experiences of vulnerability by exacerbating other challenges faced 
by older people around the home. In particular, this emphasises what Wills et al. (2013) describe as the 'Entanglement of practices' within the kitchen, showing how understanding the interrelationships between kitchen practices and packaging interactions will offer a more holistic picture of potential sources of vulnerability for older consumers who have been highlighted as having 'working against them' in the home (Dickinson et al., 2014). The accumulative effect of the physical stresses encountered as three consecutive stages of the packaging journey is befitting of Kanner et al.'s (1981) definition of daily hassles. For some older people iterative and accumulative nature of these stresses may elevate seemingly innocuous issues to more serious problems which negatively impact upon QoL.

Other themes to emerge during home storage could also be likened to daily hassles, such as products falling whilst in storage:

"It's very annoying when you buy tins that don't stack properly. So many times I've been given a bit of a fright by the noise of tins falling over in my cupboard. I don't know why they make them like that because it must be annoying for people stacking shelves in the supermarket too" - Elizabeth (72).

By improving the 'stackability' of their products, firms may be able to add value both for the senior market and for consumers at large.

\section{Opening}

The majority of participants highlighted difficulties opening packaging as a cause of dissatisfaction. This was the case for younger and older participants, including those who demonstrated a younger chronological age. For example, Janet fervently denied that age related changes had impacted on her shopping habits; however, with regards to opening packaging, she recalled a variety of negative experiences. Describing her interactions with her tin of corned beef, she alluded to the sense of fear for her personal safety that these interactions caused her:

"I push it forward and then get my finger hooked in [the ring-pull tin closure], then trying to oink it back... it's only a matter of time before I take the top of one of my fingers off' - Janet (76).

Janet was one of several participants to link difficulties opening products to biological age-related changes, describing how the frequency and severity of these issues had increased significantly. In Janet's case these changes were reductions in her hand strength as a result of primary ageing (typical age related biological changes). For 
others such as Maude, typical primary ageing changes such as these were compounded by the effects of secondary ageing (illnesses and conditions not integral to the ageing process); in this case, rheumatoid arthritis in Maude's right index finger:

"It's just one finger so you wouldn't imagine it would make much of a difference, but it really does... especially where I've not the strength I once did" - Maude (82). 
Figure 3: Janet's (76) tin of corned beef

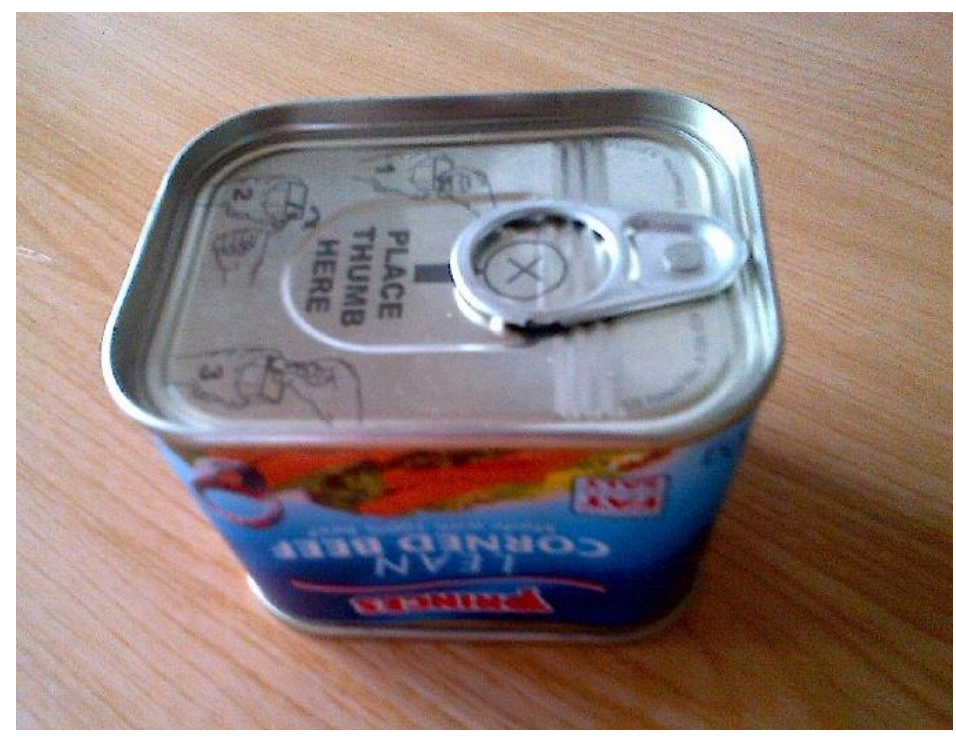


The prevalence of concerns regarding openability across participants suggests that the inclusion of 'easy-open' closures may aid firms who wish to add value for older consumers. Indeed, some participants demonstrated loyalty towards products which include 'easy-open' closures. For example, June described her experiences with 'Duerr's' jams and marmalades:

"When I first bought it I didn't even realise it had the special lid; it looks just like all the others. I even got my silicone glove out to help open it, but it flew off! I always buy that one now where I can. It's much better not having to use the glove and bash it about to get it open" - June (61). 
Figure 4: June's (61) easy-open jam jar lid

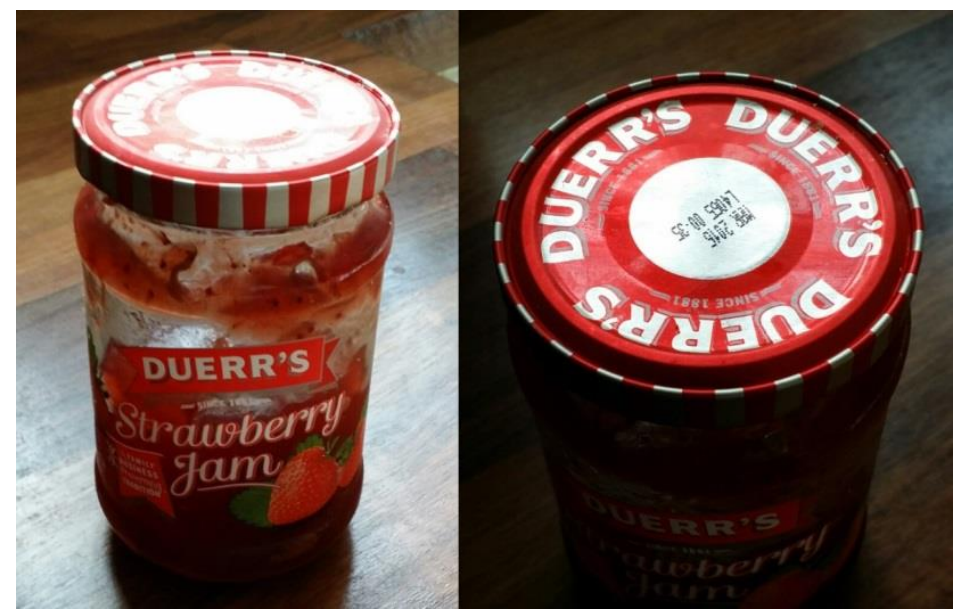


In addition to issues of gross motor skills, such as a reduction in hand strength, some participants also described difficulties with fine motor skills. For example, Bill described his experience of engaging with plastic-wrapped multi-packs of soap as "incredibly annoying", due to difficulties with gripping the seal of the pack.

"I can't get my finger nail under there...it's too fiddly. You shouldn't have to get a knife to open soap. You don't keep a knife in the bathroom" - Bill (86).

While Bill's experience elicited feelings of annoyance and frustration, other participants described feelings of apprehension and fear as a result of issues with fine motor skills and opening products:

"I much prefer a tin you open with a tin opener to a ring pull. I can never get my finger underneath to pull it up. I often feel like I'm going to break a nail, so I try and avoid them altogether. Prying it open with a knife can be as dangerous as opening anything" - June (61).

These examples highlight that while issues of gross motor skills may evoke feelings of fear and apprehension among some participants, responses to issues of fine motor skills can be just as powerful a cause of consumer vulnerability. For participants such as Maude and Bill who are among the 9 million people in the UK living with some form of arthritis (a condition most commonly found in older adults, with osteoarthritis estimated by Age UK (2015) to effect around $80 \%$ of those aged 50 and above), the likelihood of experiencing vulnerability when opening packs is particularly acute.

Upon describing their difficulties with opening particular types of packaging, several participants revealed methods for overcoming these issues. These included using a variety of implements, from sophisticated electronic jar openers, to more rudimentary tools, such as pliers and screwdrivers. These methods demonstrate consumer empowerment in response to previous experiences of vulnerability (e.g. being unable to open products or suffering injury whilst attempting to do so) or anticipated incidents of vulnerability (e.g. seeking to avoid potential injury whilst opening products). For example, Maude described the influence of her inventor brother when she unveiled her 'packaging toolbox' from underneath her kitchen sink. The toolbox contained an array of adapted household tools which were used to assist with different packs:

"In my kitchen I have these [flat-nose pliers with masking taped handles for extra grip]... those are for pulling across plastic caps. I've got a few screwdrivers to 
help lift the ring pull. I've got difficult sized ones for different sizes tins..." Maude (82).

In addition to creating her own methods for overcoming difficulties with packaging, Maude's resilient attitude was evident in a number of other ways throughout her home. For example, a mirror was placed in her lounge so that she knew by way of a flashing light on her telephone if anyone was calling her. This system was implemented as a solution to problems as a result of her reduced hearing. These problem-solving strategies demonstrate consumer empowerment in response to potential vulnerability. In the case of food products, Maude used these strategies to ensure she achieved sufficient nutritional intake: "If I didn't use my ingenuity then I probably wouldn't eat". Despite her creativity with regards to issues of openability, Maude also conceded that there are particular pack types where her problemsolving strategies are ineffective. As a result, there are products that she avoids purchasing unless there is someone to assist her. Reliance on others for help with opening packaging was apparent for a number of participants including Janet and Philippa who recalled reluctantly seeking assistance from their neighbours. Ironically, those participants who required the greatest assistance were also those with the least access to help due to aspects of social ageing. For example, participants who were empty nesters no longer had the regular assistance of children, and those who had suffered bereavement also lacked the support of their partners. Both participants, however, expressed dissatisfaction at needing to call upon others (in particular non-family members) for assistance. Philippa alluded to the negative impact this has on her self-perceptions:

"Ever since I was a child I've always been an independent person so I hate having to ask other people for help, so when I have to get my neighbour to help me open stuff because l'm too old and weak now it's quite embarrassing. You want to be able to do it yourself, but come to realise you're not the person you once were" (Philippa, 73).

Participants such as Carol who live in greater isolation have established supportive relationships with other individuals beyond, friends, family and neighbours for assistance:

"A long time ago I made an arrangement with my postman to help me with packaging. Most things I'm fine with, but products like bottles of bleach I just can't get into no matter what I try... so what I do is leave a few things on my doorstep every day and my postman comes along, opens them up for me and leaves them ready for me to get later on. I don't know what l'd do without him..." - Carol (77). 
On this occasion, it was household cleaning products which Carol required assistance from her postman with (see Figure 5). Her closing statement reveals the significance of this relationship and her apprehension when anticipating how this lack of support would affect her. It suggests feelings of uncertainty surrounding the long-term success of this coping mechanism (e.g. whether a new postman would be as helpful), evoking feelings of insecurity about her abilities to achieve her consumption goals in the future. 
Figure 5: Products to be opened by the postman

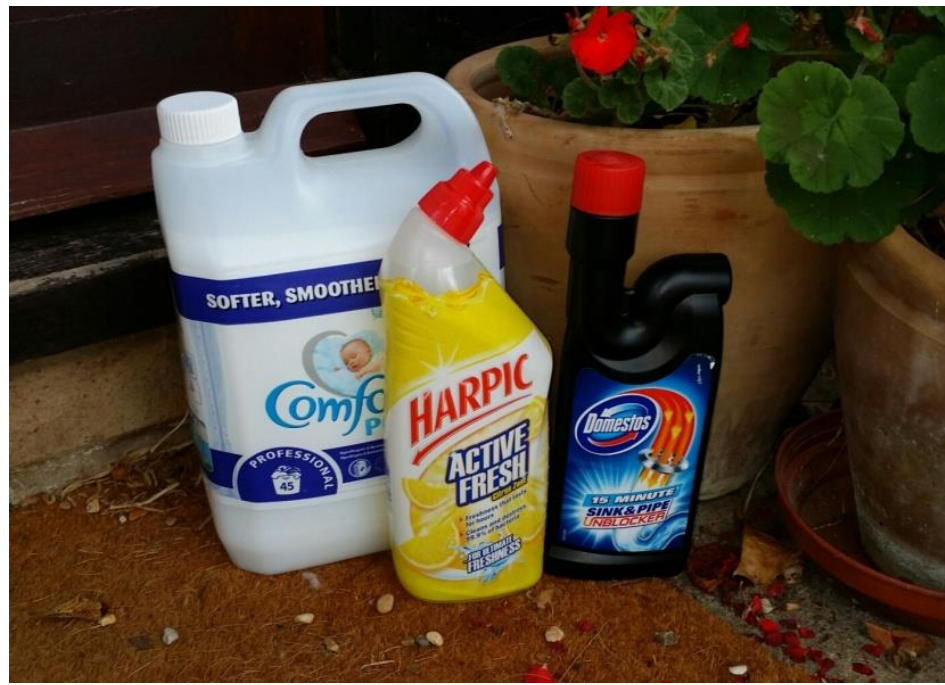




\section{Serving the product for consumption}

A cause of frustration for a number of participants was the portion sizes of many food and drink products. Evidence of the anorexia of ageing (Popper and Kroll, 2003; Dean et al., 2009) was apparent among older participants. In particular, those living alone made reference to the benefits of reduced apportionment:

"Most of the time I'll buy a pre-made salad from Waitrose for lunch. That'll normally last me two days. The big one is far too much for me and I hate to waste it' - Maude (82).

In addition to fulfilling the need for smaller portion sizes made necessary by the effects of biological ageing, social ageing was also shown to impact upon appropriate apportionment:

"As my children has grown up and left home, my shopping basket is now smaller. I don't need to buy giant sized packets of things. Especially things like breakfast cereals that go off' - Sue (62).

Several participants expressed concerns regarding the environmental impact of food wastage as a result of inappropriate apportionment. Older participants made reference to the 'waste not want not' attitude of their generation. Participants who lived during years of rationing expressed particular dismay toward wastage, be that food waste or packaging waste. This suggests that firms would benefit from considering both micro factors affecting the process of ageing for individuals, and macro factors such as major political and cultural events which may impact upon consumers' values and opinions across the life course. However, participants such as Bill (86) also revealed negative associations between food wastage and biological ageing. Recalling their youth, Bill (86) reflected on changes to his and his wife's appetites and the influence this has on their consumption habits:

"I never buy packed meats. I always get it from the deli counter. If I want a slice of turkey I want one slice, not six or seven slices. The situation I'm in, there's just two of us and my wife's not a big eater anymore...she'll have a slice of bread in half for a sandwich... anymore would go to waste" - Bill (86).

The availability of meats in smaller portions offered Bill more satisfying consumption experiences by avoiding actions (e.g. wasting food as a result of reductions in his appetite) which triggered negative associations with biological ageing. Use of the delicatessen therefore acts as a form of consumer empowerment. However, for other products this solution was not possible (e.g. ambient food products). For other participants such as 
Elizabeth who had experienced reductions in appetite, excessive food portion sizes acted as a reminder of negative aspects of the ageing process:

"I try and get smaller packs, but a lot of the time I can't find them. It means I often don't finish things. It's such a waste. I'm sure this will sound very selfish, but it's horrible for me too in that you think 'it didn't used to be like this'. I think I associate eating with family and my husband, so eating less reminds me that he's not around anymore" (Elizabeth, 72).

Like several others, Bill encountered difficulties with reading labels. He bemoaned the small font used on his ginger sponge pudding (Figure 6), describing the cooking instructions as "bloody useless" while recalling a number of incidents where his dessert had been unsatisfyingly tepid or dangerously hot having not been able to read the instructions. This example demonstrates the importance of packaging in delivering value to consumers; the satisfaction gained from the core product is facilitated by the consumers' interaction with the packaging. Whilst Bill's experience evoked feelings of annoyance, it also highlights more significant issues regarding the health and safety during food preparation. If cooking instructions, storage instructions, or 'use-by' dates are illegible this risks food being inadequately prepared, potentially leading to increased risk of contracting food-borne illnesses (Wills et al., 2013). Finally, participants' difficulties encountered whilst serving products for consumption also further demonstrates how packaging interactions can contribute to experiences of vulnerability and reflects the accumulative build-up of stresses encountered during several consecutive stages of the packaging journey. 
Figure 6: Bill's (86) ginger sponge pudding packaging with small font

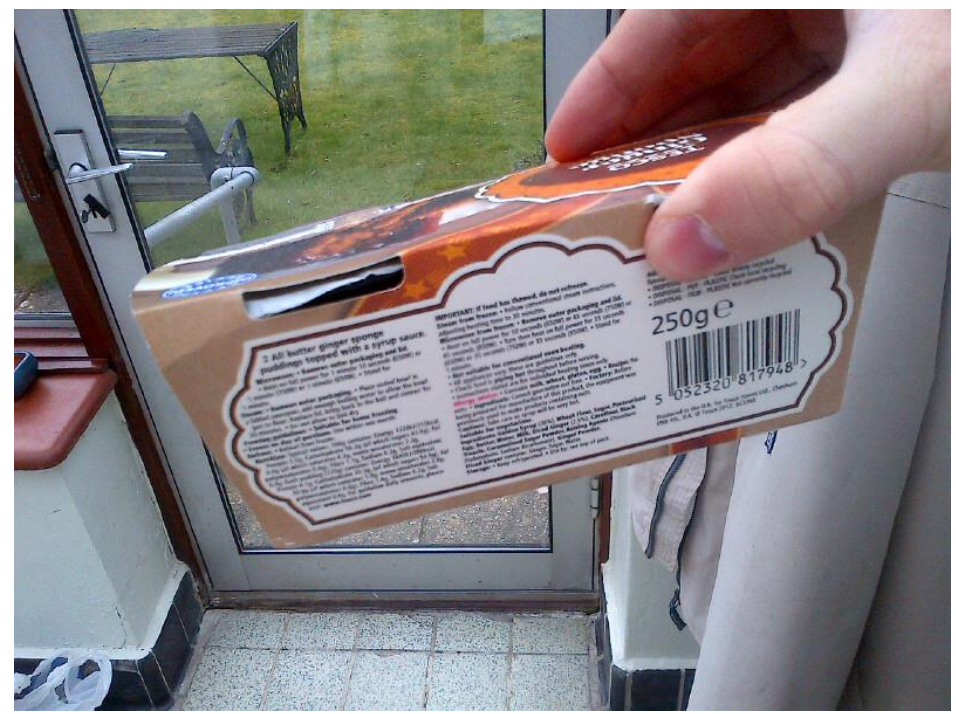




\section{Reclosing or putting away}

Several participants expressed a desire for re-sealable packaging, highlighting this form of user convenience as a possible solution to issues with apportionment. However, dissatisfaction was expressed towards current re-sealable packaging solutions. For example, Philippa described her negative experiences with re-sealable cheese packets (both 'zip-lock' and adhesive seals):

"I don't get on with them. It's probably not their [the manufacturer] fault though, it's more me doing it wrong" - Philippa (73).

Philippa's feelings of self-blame were typical of the many participants who suffered difficulties with packaging. For example, June blamed herself for her difficulties attempting to read labels in-store, describing herself as "foolish" for not having her spectacles to hand. According to Stephens and Gwinner (1998, p. 182), in some cases of self-blame, consumers truly believe a negative consumption experience is a result of their own actions; however, in many cases individuals will convince themselves that they are to blame. Blaming one's self is perceived as being easier than the challenge of voicing complaint. In the case of negative packaging experiences, the distance between consumers and packaging manufacturers may also lead individuals to use self-blame coping tactics more readily than with negative retail experiences. For participants such as Philippa and June, much of this self-blame is manifested by negative perceptions of biological ageing. This then has implications for psychological ageing; self-blame elicits feelings of uselessness and inadequacy which negatively impact upon an individual's self-concept and, in turn, their QoL:

"The idea of getting older I'm okay with... but it's everyday stuff like this when you realise how your body is changing and how it already is affecting the way you go about your life... that's what gets you down" June (61).

In particular for older participants such as Yvonne, the accumulation of stresses experienced across the packaging journey was evident:

"I don't like to moan because I'm sure people have far greater problems, but it does feel like the problems are never-ending. Whether it's getting to the shops, getting round the shops, or even putting the stuff away when I get back, things are hard" (Yvonne, 81).

With regards to larger products, this stage of the packaging journey represented further continuation of physiological difficulties lifting and storing products. Much like the long-term damage caused by the accumulative effect of daily hassles (Lay and Safdar, 2003), the 
stresses experienced during the process of locating, transporting, storing, using, putting away, reusing and disposing of a product may also cause profound harm to an individual's QoL.

\section{Disposal}

Several participants described environmental concerns towards particular forms of packaging as influencing their purchasing decisions. At the point of disposal, these concerns arose again. In addition to the excessive 'over-packing' of products, several participants expressed a desire for recyclable packaging materials. The ubiquity of non-recyclable plastics was a particular cause of frustration for several participants. For example, participants such as Jim (63) and June (61) described their annoyance over plastic packaging and subsequent feelings of guilt during disposal. In addition to recycling and avoiding 'over-packaged' products, a number of participants also described methods for reusing packs. For example, June (61) expressed her disappointment at changes to the packaging of 'Vitalite' dairy-free spreads; 'Vitalite' had previously been packaged in wide, shallow circular containers but are now in taller, narrowed rectangular containers which resemble rival products more closely:

"I used to always buy Vitalite as the packaging was so useful afterwards. I never buy it anymore. Since the tub is much the same as all the others I tend to just go for whatever's cheapest now" - June (61).

June's (61) former loyalty to Vitalite demonstrates the value-adding potential of packaging. While FMCG firms may be under increasing retailer pressure to conform to shelf-space requirements, these insights suggest that firms may be able to achieve competitive advantage through unique reusable packaging. While government bodies such as WRAP have previously encouraged firms to reduce packaging weight, these examples suggest that equal consideration should also be given to reusable packaging. In so doing, firms may be able to both reduce the environmental impact of their packaging, while also adding value for a greater variety of consumer segments.

\section{Discussion:}

Our findings illustrate the inseparable nature of the multiple dimensions of ageing (Riley, 1985). While prior research has emphasised the impact of biological ageing on packaging interactions (e.g. Lewis et al., 2007; Yoxall, Luxmoore and Rowson 2008), our findings 
suggest that aspects of psychological and social ageing may also contribute to experiences of vulnerability. Consumer vulnerability can occur when an individual's self-concept is harmed by being unable to achieve their consumption goals (Baker, Gentry and Rittenburg, 2005). In this study, social ageing and a variety of life transitions older consumers are more likely to experience than other groups (e.g. becoming an empty-nester or becoming widowed) were found to influence participants' abilities to achieve their consumption goals. For example, whilst biological ageing may affect abilities to open products due to changes in strength and dexterity, social ageing may exacerbate this further if an individual is living in isolation and has limited assistance available to them. This may compound the negative influence on one's self-concept of being unable to achieve consumption goals, in particular where difficulties serve as a reminder of the negative aspects of the ageing process. For example, relying on others for assistance due to physical difficulties encountered across the packaging journey. In such cases, older people may come to associate with negative stereotypes of older age (Sudbury-Riley, 2014), thus potentially further perpetuating changes which could contribute to increased vulnerability. In this way, difficulties with packaging which frustrate or irritate consumers at large may serve as a source of vulnerability for older people due to age-related changes. Whilst consumer vulnerability is often a "short-run phenomenon that does not become an equilibrium state" (Baker, Gentry and Rittenburg, 2005, p. 136), the frequency of engagement with FMCG products and multiple interactions they entail mean that consumers may encounter multiple episodic experiences of vulnerability. The regularity of these experiences bares comparison with the concept of daily hassles. In the same way that daily hassles have been linked to psychological stress among older people (e.g. Lau, Wai and Shiu, 1996; Kraaij, Arensman and Spinhoven, 2002; Sher, 2004), the iterative accumulation of difficulties encountered across the packaging journey may contribute to consumer vulnerability in a way that has not been fully captured in prior literature.

According to Baker, Hunt and Rittenburg (2007, p. 134), in order for consumers to achieve success in the marketplace they require the "knowledge, skills and freedom" to achieve their goals. In some cases, packaging can restrict consumers' knowledge of a product and freedom to inspect and observe items, thus contributing to vulnerability. This was demonstrated in several participants' desire for transparent packaging. Feelings of cynicism and mistrust towards marketing communications images were directly attributed by some participants to increased awareness and knowledge of marketing communications techniques gathered across the life-course. The wisdom gathered through a lifetime of knowledge accumulation, means that older people may seek more product information before purchasing (e.g. Dychtwad, 1997; Myers and Lumbers, 2008). Such information 
gathering can act as a coping mechanism to instil a greater sense of control of consumption activities. This further reinforces the need to conceptualise ageing as a multidimensional process and packaging as a multifunctional tool when attempting to understand sources of vulnerability among older consumers. The potential impact of changes to eyesight as people age on the ability to decipher information from packaging further illustrates this need. As such, whilst individual characteristics and states mean that younger people may also experience feelings of mistrust towards packaging imagery (and other issues with packaging), the ageing process may increase the likelihood of older people encountering these experiences and exacerbate the negative impact they have.

The variety of problem-based coping mechanisms exhibited by the participants demonstrates high levels of mastery (Ben-Zur, 2002) and evidence of a "perceived ability to significantly alter events" (Burger, 1989, p.246). This confirms the view of Lee, Ozanne and Hill (1999) that consumers are not passive recipients of vulnerability but in fact utilise their own resources to overcome, reduce, and circumvent issues encountered within the marketplace. However, while the mastery and stoicism demonstrated may positively contribute to QoL, this did not exempt those participants from experiences of vulnerability. While many difficulties with packaging were befitting of Kanner et al.'s (1981) description of daily hassles as being irritating or frustrating, the negative effects for some participants were of greater significance. In cases where coping mechanisms proved ineffective, several participants exhibited feelings of uselessness and self-reproach following negative experiences with packaging. According to Clough (2015, p. 133), many older people "see themselves as independent if they continue to be able to direct the way that something is done even though they may not be able to do it themselves". However, our findings illustrate a desire to maintain personal control over packaging interactions without outside assistance. The regularity with which people engage with packaging, and which characterises daily hassles, may mean that independence is viewed in this context as the ability to perform tasks oneself. Participants' perceptions of requests for assistance with packaging problems as being embarrassing or burdensome are indicative of this. This suggests that firms may be able to offer older people considerable value through packaging development and reduce the likelihood of experiencing vulnerability.

\section{Conclusions:}

This study has contributed to the consumer vulnerability literature by exploring the concept in a new and unique context. Our study has provided insights which may offer scope to deepen our understanding of consumer vulnerability. Specifically, two contributions to the literature 
are made. Firstly, our exploration has not only uncovered experiences of actual vulnerability (e.g. participants expressing feelings of powerlessness due to interactions with packaging), but also examples of 'anticipated vulnerability'. Prior studies have distinguished between actual and perceived vulnerability (e.g. Laufer and Gillespie, 2004; Baker, Gentry and Rittenburg, 2005; Hogg, Howells and Milman, 2007). However, conceptualisations of perceived vulnerability have primarily been outward focused - entailing the attribution of vulnerability from one person to another. The narrations of our participants suggest that awareness of ageing may evoke a form of anticipatory self-perceived vulnerability, where harm or negative consumption experiences are foreseen and responded to. Experiences shared by participants suggest that anticipated vulnerability can influence behaviour, even in incidences where the envisioned experience has yet to occur. These findings suggest that greater awareness of the effects of ageing may not only shift motivations and personal goals (e.g. Cole et al., 2008; Drolet et al., 2010), but also contribute to heightened awareness of potential sources of vulnerability. This heightened awareness may relate to a variety of marketplace interactions and contexts. In particular, contexts where there is a greater degree of separation between the consumer and product manufacturer (e.g. packaging) where support from the firm may be perceived as unobtainable or difficult to access. This degree of separation may also, therefore, contribute to feelings of helplessness. In addition to short-term predictions of vulnerability (e.g. anticipating potential injury when opening packs), some younger participants also exhibited longer-term predictions such as greater use of alternative retail channels to overcome difficulties when shopping.

Secondly, our exploration of older consumers' packaging interactions offers a new lens with which to examine consumer vulnerability; one which considers the effects of daily hassles on vulnerability. Whilst seemingly innocuous when considered in isolation, the experiences shared by our participants suggest that the gradual build-up and continuation of stresses can lead to sustained feelings of frustration and powerlessness. Paradoxically, packaging was found to act as a both a cause of potential vulnerability (e.g. closures which require excessive opening forces), as well as an alleviator (e.g. distinctive packs instilling a sense of control in busy retail environments). This suggests that FMCG firms may be able to utilise packaging development to aid older people in avoiding experiences of vulnerability and maintaining independent lives. Where packaging acted as a contributor to vulnerability, participants exhibited a variety of problem-solving strategies. However, where such strategies proved ineffective, reliance was placed on external factors (in this case, managers involved in the development of new FMCG packaging and retail service development) to create fairness in the marketplace. Whilst previous studies have focused largely on individual events or specific marketplace interactions acting as sources of consumer 
vulnerability, exploration of packaging interactions suggests that equal consideration should be given to the accumulation of smaller, less conspicuous interactions. When viewed as isolated incidents, specific problems illustrated in our findings may appear to act only as a source of irritation, rather than vulnerability. However, the combined impact of multiple sources of irritation on a frequent basis were found to contribute to extended feelings of diminished control over consumption experiences. This loss of control can negatively affect consumers' self-concepts. Therefore, the daily hassles encountered with packaging may contribute to consumer vulnerability.

\section{Implications, limitations and future research:}

Based on our findings, implications for managers can be identified. Packaging was found to both contribute to and ameliorate experiences of vulnerability. This suggests that FMCG firms may be able to utilise packaging development to aid older people in avoiding experiences of vulnerability and maintaining independent lives. However, further research is required to determine appropriate product positioning strategies for firms hoping to deliver value to older consumers within a multi-demographic retail context. A number of authors warn that products positioned clearly towards the senior market may alienate older consumers who do not wish to purchase products which label them as 'old' (Schewe, 1991; Turley, 1994; Plummer, 2009), thus also affecting adoption among other consumers. Inclusive design has been proposed as a more viable approach to delivering value to older consumers, as well as consumers at large (Clarkson et al., 2003; Persad et al., 2007; Clarkson and Coleman, 2010). This would be commercially beneficial given the propensity for younger consumers to also experience some of the difficulties with packaging detailed in this study. However, as evidenced by the experiences of June who failed to recognise the easy-open closure of her jam jar, firms may also encounter challenges when adopting an inclusive design approach; in this case, achieving a balance between communicating the functional benefits of the products to those consumers who will receive the greatest benefit (e.g. older people or disabled people), whilst maintaining mass market appeal. Potentially, a balance could be struck between positioning strategies through the inclusion of icons such as the 'Owl Mark' created by The Centre for Applied Gerontology at the University of Birmingham; a quality mark which accredits products as suitable for the needs of older people (Coleman, 2009). For FMCG products, this could provide a more subtle indication of a pack being easier to open.

The findings also highlight potential implications for product apportionment. Specially, the provision of products with reduced apportionment may positively contribute to QoL for older 
consumers in several ways: firstly, by better meeting some individuals' biological needs in terms of appetites and allowing for easier transportation and storage of products; secondly, by facilitating regular shopping habits, thus incorporating changes of social ageing; and thirdly, by positively contributing to psychological ageing by avoiding actions which trigger negative associations with biological ageing (e.g. wasting food). Given the growth of convenience stores in the UK (Barford, 2014), individualised apportionment may also offer firms that wish to target a wider market whilst better integrating the needs of older consumers a means of adding value through packaging development, thus integrating the needs of a multi-demographic retail environment.

Evidence of choice paradox among participants reveals opportunities for firms to add value for older consumers by strategically aligning packaging development, retail service development and product assortment planning (PAP) decision-making (c.f. Mantrala et al., 2009). For example, by aligning packaging development with PAP decisions, firms may be able to tailor both packaging development and retail service development to offer greater value to older consumers. This may involve using consumer education programmes to encourage consumers to purchase larger items online. This would not only facilitate the inclusion of clearer labelling and help to alleviate physiological difficulties with transporting large goods, but also allow for the dedication of space in tangible stores to value-adding facilities which encourage social interaction (e.g. delicatessen counters).

Whilst providing valuable insights on which to build future research, this study has several limitations. Firstly, based on the modest sample size, there is a need for further research exploring the packaging interactions of a greater number of older consumers. Additional qualitative research supported by larger scale quantitative studies would be advantageous in this regard and would allow for more detailed examination of how ageing affects packaging interactions over time. The choice of qualitative interviews has limitations in that some consumers' packaging experiences may be different to events they recall. Conducting participant observations overcomes this limitation to an extent, however there is a need for further in-depth investigation in this regard. In particular, research exploring consumer vulnerability from a daily hassles perspective and investigations into the influence of anticipated vulnerability of behaviour in a variety of consumption contexts would provide valuable contributions to the current body of knowledge. Finally, whilst this study has offered some insights into older consumers' experiences in FMCG retail environments, further research is required to better understand the relationships between older consumers' packaging needs and retail environments and how this affects sources of potential vulnerability. 


\section{References:}

Adkins, N. R., \& Jae, H. (2010). Marketplace Vulnerability of Limited English

Proficient Consumers: Opportunities to increase Knowledge in Marcomarketing. Journal of Macomarketing, 30(1), 93-104.

Adkins, N. R., \& Ozanne, J. L. (2005). The Low Literature Consumer. Journal of Consumer Research, 32(1), 93-105.

Adler, P., \& Adler, P. (1987). Membership Roles in Field Research. Newbury Park: Sage Publications.

Agency, F. S. (2013). Domestic Kitchen Practicses: Findings from the 'Kitchen Life' study. University of Hertfordshire. doi:http://www.food.gov.uk/sites/default/files/818-11496_KITCHEN_LIFE_FINAL_REPORT_10-07-13.pdf

Ahmad, R. (2002). The older or ageing consumers in the UK: are they really that different? International Journal of Market Research, 44(3), 337-360.

Almeida, D. M. (2005). Resilience and Vulnerability to Daily Stressors Assessed Using Diary Methods. Current Directions in Psychological Science, 14(2), 6468.

Alves, L. M., \& Wilson, S. R. (2008). The Effects of Loneliness on Telemarketing Fraud Vulnerability Among Older Adults. Journal of Elder Abuse \& Neglect, 20(1), 63-85. doi:10.1300/J084v20n01_04

Ampuero, O., \& Vila, N. (2006). Consumer perceptions of product packaging. Journal of Consumer Marketing, 23(2), 100-112.

Baker, S. M. (2006). Consumer normalcy: Understanding the value of shopping through narratives of consumers with visual impairments. Journal of Retailing, 82(1), 37-50. 
Baker, S. M., Gentry, J. W., \& Rittenburg, T. L. (2005). Building Understanding of the Domain of Consumer Vulnerability. Journal of Macromarketing, 25(2), 128139.

Baker, S. M., Hunt, D. M., \& Rittenberg. (2007). Consumer Vulnerability as a Shared Experience: Tornado Recovery Porcess in Wright, Wyoming. Journal of Public Policy and Marketing, 26(1), 6-19.

Barford, V. (2014, January 17). The rise, fall and rise of the mini supermarket. Retrieved June 14, 2014, from BBC News: http://www.bbc.co.uk/news/magazine-25762466

BBC. (2004). 'Wrap rage' hitting the over-50s. Retrieved March 17, 2012, from http://news.bbc.co.uk/1/hi/business/3456645.stm

Becker, H. S. (1958). Problems of Inference and Proof in Participant Observations. American Sociological Review, 23(6), 652-660.

Becker, L., van Rompany, T. J., Schifferstein, H. N., \& Galetzka, M. (2011). Tough package, strong taste: The influence of packaging design on taste impressions and product evaluations. Food Quality and Preference, 22(1), 1723.

Belk, R., Fischer, E., \& Kozinets, R. (2013). Qualitative Consumer \& Marketing Research. London: SAGE Publications Ltd.

Bengston, V. L., Putney, N. M., \& Johnson, M. L. (2005). The Problem of Theory in Gerontology Today. In M. L. Johnson (Ed.), The Cambridge Handbook of Age and Ageing. Cambridge: Cambridge University Press.

Ben-Zur, H. (1999). The effectiveness of coping meta-strategies: perceived efficiency, emotional correlates, and cognitive performance. Personality and Individual Differences, 26(5), 923-939.

Ben-Zur, H. (2002). Coping, affect and aging: the role of mastery and self-esteem. Personality and Individual Differences, 32(2), 357-372.

Birren, J. E. (1959). Handbook of aging and the individual. Chicago: The University of Chicago Press. 
Birren, J. E., \& Schaie, K. W. (2001). Handbook of the Pyschology of Aging. London: Academic Press.

Blocker, C. P., Ruth, J. A., Sridharan, S., Beckwith, C., Ekici, A., Goudie-Hutton, M., . . Varman, R. (2013). Understanding poverty and promoting poverty alleviation through transformative consumer research. Journal of Business Research, 66(8), 1195-1202.

Bond, J., Peace, S., Dittmann-Kohli, F., \& Westerhof, G. (2007). Ageing in Society. London: Sage.

Bowling, A. (2005). Ageing Well: Quality of Life in Old Age. Maidenhead: Open University Press.

Bowling, A., Seetai, S., Morris, R., \& Ebrahim, S. (2007). Quality of life among older people with poor functioning. The influence of perceived control over life. Age and Ageing, 36(3), 310-315.

Broderick, A. J., Demangeot, C., Adkins, N. R., Ferguson, N. S., Henderson, G. R., Johnson, G., .. Zuniga, M. A. (2011). Consumer Empowerment in Multicultural Marketplaces: Navigating Multicultural Identities to Reduce Consumer Vulnerability. Journal of Research for Consumers, 19(1), 1-13.

Brown, G. W., Bhrolchain, M. N., \& Harris, T. (1975). Social Class and Psychiatric Disturbance among Women in an Urban Population. Sociology, 9(2), 225-254. doi:10.1177/003803857500900203

Bryman, A., \& Bell, E. (2007). Business Research Methods. Oxford: Oxford University Press.

Burger, J. M. (1989). Negative reactions to increases in perceived personal control. Journal of Personality and Social Psychology, 56(2), 246-256.

Burgess, R. G. (1984). In the Field: An Introduction to Field Research. London: Allen \& Unwin.

Campisi, J., \& d'Adda di Fagagna, F. (2007). Cellular senescence: when bad things happen to good cells. Nature Reviews Molecular Cell Biology, 8(9), 729-740. 
Caner, C., \& Pascall, M. A. (2010). Consumer complaints and accidents related to food packaging. Packaging Technology and Science, 23(7), 413-422.

Carrigan, M., Szmigin, I., \& Wright, J. (2004). Shopping for a better world? An interpretive study of the potential for ethical consumption within the older market. Journal of Consumer Marketing, 21(6), 401-417.

Clarkson, J., \& Coleman, R. (2010). Inclusive design. Journal of Engineering Design, 21(2-3), 127-129.

Clarkson, J., Coleman, R., Keates, S., \& Lebbon, C. (2003). Inclusive Design: Design for the whole population. London: Springer-Verlag.

Clough, R. (2015). Older people: Citizens in a consumer society. In K. Hamilton, S. Dunnett, \& M. Piacentini (Eds.), Consumer Vulnerability: Conditions, contexts and characteristics (pp. 130-142). Abingdon: Routledge.

Cole, C., Lauren, G., Drolet, A., Ebert, J., Gutchess, A., Lambert-Pandraud, R., . . . Peters, E. (2008). Decision making brand choice by older consumers. Marketing Letters, 19(3-4), 355-365.

Coleman, R. (1999). Inclusive Design. In W. S. Green, \& P. W. Jordan (Eds.), Human Factors in Product Design: Current Practice and Future Trends (pp. 159-171). London: Taylor \& Francis.

Commuri, S., \& Ekici, A. (2008). An Enlargement of the Notion of Consumer Vulnerability. Journal of Macromarketing, 28(2), 183-186.

Cowart, K. O., \& Darke, P. (2014). Targeting Miss Daisy: Using age and gender to target unethical sales tactics. Marketing Letters, 25(1), 67-75.

Czaja, S. J., \& Lee, C. C. (2007). The impact of aging on access to technology. Universal Access in the Information Society, 5(4), 341-349.

Dean, M., Raats, M. M., \& Grunert, K. G. (2009). Older people, food and satisfaction with life. In M. Dean, M. M. Raats, \& K. G. Grunert (Eds.), Food for the ageing population (pp. 3-15). Boca Raton: Woodhead Publishing Limited. 
den Uijl, L. C., Jager, G., de Graaf, C., Waddell, J., \& Kremer, S. (2014). It is not just a meal, it is an emotional experience - A segmentation of older persons based on the emotions that they associate with mealtimes. Appetite, 83(1), 287-296. doi:10.1016/j.appet.2014.09.002

Devendorf, M., \& Lewis, K. (2010). Designing a Product Package Platform. ASME 2010 International Design Engineering Technical Conferences \& Computers and Information in Engineering Conference. Montréal.

Dickinson, A., Wills, W., Meah, A., \& Short, F. (2014). Food safety and older people: the Kitchen Life study. British Journal of Community Nursing, 19(5), 226-232. doi:10.12968/bjcn.2014.19.5.226

Drolet, A., Lau-Gesk, L., Williams, P., \& Jeong, H. G. (2010). Socioemotional Selectivity Theory: Implications for Consumer Research. (A. Drolet, N. Schwarz, \& C. Yoon, Eds.) Hove: Routledge.

Duizer, L. M., Robertson, T., \& Han, J. (2009). Requirements for packaging from an ageing consumer's perspective. Packaging Technology and Science, 22(4), 187-197.

East, R., Uncles, M. D., \& Lomax, W. (2014). Hear nothing, do nothing: the role of world of mouth in the decision-making of older consumers. Journal of Marketing Management, 30(7-8), 786-801.

Elms, J., \& Tinson, J. (2012). Consumer vulnerability and the transformative potential of Internet shopping: An exploratory case study. Journal of Marketing Management, 28(11), 1354-1376. doi:10.1080/0267257X.2012.691526

Evelyne, B., Marion, M., \& Bernaud, J.-L. (2007). Daily hassles and depressive symptoms among first year psychology students in France: the role of coping and social support. Stress \& Health: Journal of the International Society for the Investigation of Stress, 23(2), 93-99.

Fitzgerald, T. E., Tennen, H., Affleck, G., \& Pransky, G. S. (1993). The relative importance of dispositional optimism and control appraisals in quality of life after coronary artery bypass surgery. Journal of Behavioral Medicine, 16(1), 25-43. 
Flick, U. (2009). An Introduction to Qualitative Research. London: SAGE Publications Ltd.

Glaser, B. G., \& Strauss, A. L. (1967). The Discovery of Grounded Theory. Chicago: Aline.

Goddard, N., \& Nicolle, C. (2012). What is Good Design in the Eyes of Older Users? In P. Langdon, J. Clarkson, P. Robinson, J. Lazar, \& A. Heylighen (Eds.), Designing Inclusive Systems: Designing Inclusion for Real-world Applications (pp. 175-183). London: Springer-Verlag.

Greco, A. J. (1986). The fashion-conscious elderly: a viable, but neglected market segment. Journal of Consumer Marketing, 3(4), 71-75.

Griffiths, M. A., \& Harmon, T. R. (2011). Aging Consumer Vulnerabilities Influencing Factors of Acquiescence to Informed Consent. Journal of Consumer Affairs, 45(3), 445-466. doi:10.1111/j.1745-6606.2011.01212.x

Grougiou, V., \& Pettigrew, S. (2009). Seniors' attitudes to voicing complaints: a qualitative study. Journal of Marketing Management, 25(9-10), 987-1001.

Gubrium, J. F., \& Sankar, A. (1994). Qualitative Methods in Aging Research. London: Sage.

Gunter, B. (1998). Understanding the older consumer. London: Routledge.

Hare, C., Kirk, D., \& Lang, T. (1999). Identifying the expectations of older food consumers: More than a "shopping list" of wants. Journal of Marketing Practice, 5(6), 213-232.

Hogg, M., Howells, G., \& Milman, D. (2007). Consumers in the Knowledge-Based Economy (KBE): What creates and/or constitutes consumer vulnerability in the KBE? Journal of Consumer Policy, 30(2), 151-158. doi:10.1007/s10603007-9030-9

Hooyman, N. R., \& Kiyak, H. A. (2008). Social Gerontology: A Multidisciplinary Perspective. London: Pearson. 
Hudson, P. K., \& Hartwell, H. J. (2002). Food safety awareness of older people at home: a pilot study. The Journal of the Royal Society for the Promotion of Health, 122(3), 165-169.

Hughes, G., Bennett, K., \& Hetherington, M. (2004). Old and alone: barriers to healthy eating in older men living on their own. Appetite, 43(1), 269-279.

Hunter-Jones, P. (2011). Consumer vulnerability and exclusion: A study of carers in the tourism marketplace. Journal of Marketing Management, 27(1), 165-180. doi:10.1080/02672571003737809

ILC. (2010). The Golden Economy: The Consumer Marketplace in an Ageing Society. Retrieved March 17, 2012, from http://www.ilcuk.org.uk/images/uploads/publication-pdfs/pdf_pdf_155.pdf

Jeon, H.-S., Dunkle, R., \& Roberts, B. L. (2006). Worries of the Oldest-Old. Health \& Social Work, 31(4), 256-265.

Kane, R. L., \& Kane, R. A. (2000). Assessing older persons: measuring, meaning and practical applications. Oxford: Oxford University Press.

Kanner, A. D., Coyne, J. C., Schaefer, C., \& Lazarus, R. S. (n.d.). Comparison of Two Modes of Stress Measurement: Daily Hassles and Uplifts Versus Major Life Events. Journal of Behavioral Medicine, 4(1), 1-39.

Kirkwood, T. (2009). Enrich Your Future. Retrieved January 2, 2015, from https://www.dana.org/uploadedFiles/The_Dana_Alliances/European_Dana_Al liance_for_the_Brain/tomkirkwood_enriching_yourfuture.pdf

Kohlbacher, F., \& Herstatt, C. (Eds.). (2010). The Silver Market Phenomenom. London: Springer.

Kose, S. (1997). Dwelling Design Guidelines for Accessibility in the Aging Society. In S. Wapner, J. Demick, T. Yamamoto, \& T. Takahashi (Eds.), Handbook of Japan-United States Environment-Behavior Research: Toward A Transactional Approach (pp. 25-42). New York: Springer.

Kuypers, J. A., \& Bengston, V. L. (1973). Social Breakdown and competence: A model of normal aging. Human Development, 16(3), 181-201. 
Langenderfer, J., \& Shimp, T. A. (2001). Consumer vulnerability to scams, swindles, and fraud: A new theory of visceral influences on persuasion. Pscyhology \& Marketing, 18(7), 763-783. doi:10.1002/mar.1029

Laufer, D., \& Gillespie, K. (2004). Differences in Consumer Attributions of Blame between Men and Women: The Role of Perceived Vulnerability and Empathic Concern. Psychology and Marketing, 21(2), 141-157. doi:10.1002/mar.10119

Lay, C. H., \& Safdar, S. F. (2003). Daily hassles and distress among college students in relation to immigrant and minority status. Current Psychology, 22(1), 3-22.

Lazarus, R. S., \& Folkman, S. (1984). Stress, Appraisal and Coping. New York: Springer.

Lee, J., \& Geistfeld, L. V. (1999). Elderly Consumers' Receptiveness to Telemarketing Fraud. Journal of Public Policy \& Marketing, 18(2), 208-217.

Lee, J., \& Soberon-Ferrer, H. (1997). Consumer Vulnerability to Fraud: Influencing Factors. Journal of Consumer Affairs, 31(1), 70-89. doi:10.1111/j.17456606.1997.tb00827.x

Leventhal, R. C. (1997). Aging consumers and their effects on the marketplace. Journal of Consumer Marketing, 14(4), 276-281.

Lewis, R., Menardi, C., Yoxall, A., \& Langley, J. (2007). Finger friction: Grip and opening packaging. Wear, 263(7-12), 1124-1132.

Lincoln, Y. S., \& Guba, E. G. (1985). Naturalistic Inquiry. London: Sage.

Lords, H. o. (2013, March 14). Ready for Ageing? Report. Retrieved January 2 , 2015, from House of Lords: http://www.publications.parliament.uk/pa/ld201213/ldselect/ldpublic/140/140.p df

Lunsford, D. A., \& Burnett, M. S. (1992). Marketing Product Innovations to the Elderly: Understanding the Barriers to Adoption. Journal of Consumer Marketing, 9(4), 53-62. 
Lyon, P., Kinney, D., \& Colquhoun, A. (2002). Experience, change and vulnerability: consumer education for older people revisited. International Journal of Consumer Studies, 26(3), 178-187.

Mantrala, K. M., Levy, M., Kahn, B. E., Fox, E. J., Gaidarev, P., Dankworth, B., \& Shah, D. (2009). Why is Assortment Planning so Difficult for Retailers? A Framework and Research Agenda. Journal of Retailing, 85(1), 71-83.

Marvasti, A. B. (2014). Analysing Observations. In U. Flick, The SAGE Handbook of Qualitative Data Analysis (pp. 354-366). London: Sage.

Mathur, A., \& Moschis, G. P. (2005). Antecedents of Cognitive Age: A Replication and Extension. Psychology \& Marketing, 22(12), 969-994.

McCracken, G. (1988). The Long Interview. Newbury Park: Sage.

McGhee, J. L. (1983). The vulnerability of elderly consumers. International Journal of Aging Human Development, 17(3), 223-246.

McKee, D., \& Vilhjalmsson. (1986). Life Stress, Vulnerability, and Depression: A Methodological Critique of Brown et al. Sociology, 20(4), 589-599. doi:10.1177/0038038586020004008

Miles, M. B., \& Huberman, A. M. (1994). Qualitative Data Analysis: An Expanded Sourcebook. London: Sage.

Moen, P., Dempster-McClain, D., \& Williams Jr., R. M. (1992). Successful Aging: A Life-Course Perspective on Women's Multiple Roles and Health. American Journal of Sociology, 97(6), 1612-1638.

Moschis, G. P. (1992). Gerontographics: A Scientific Appraoch to Analyzing and Targeting the Mature Market. Journal of Services Marketing, 6(3), 17-26.

Moschis, G. P., Mosteller, J., \& Fatt, C. K. (2011). Research Frontiers on Older Consumers' Vulnerability. Journal of Consumer Affairs, 45(3), 467-491.

Mumel, D., \& Prodnik, J. (2005). Grey consumers are all the same, they even dress the same - myth or reality? Journal of Fashion Marketing and Management, 9(4), 434-449. 
Myers, H., \& Lumbers, M. (2008). Understanding older shoppers: a phenomenological investigation. Journal of Consumer Marketing, 25(5), 294301.

Nag, R., Corley, K. G., \& Gioia, D. A. (2007). The Intersection of organization identity, knowledge, and practice: Attempting strategic change via knowledge grafting. The Academy of Management Journal, 50(4), 821-847.

Nancarrow, C., Wright, L. T., \& Brace, I. (1998). Gaining competitive advantage from packaging and labelling in marketing communications. British Food Journal, 100(2), 110-118.

Nayak, U. S. (1998). How can products be made safer for use by older people? International Journal for Consumers \& Product Safety, 5(2), 91-98.

Noor, K. B. (2008). Case Study: A Strategic Research Methodology. American Journal of Applied Science, 5(11), 1602-1604.

Oumlil, A. B., \& Williams, A. J. (2000). Consumer education programs for mature consumers. Journal of Services Marketing, 14(3), 232-243.

Pak, C., \& Kambil, A. (2006). Over 50 and ready to shop - serving the ageing consumer. Journal of Business Strategy, 27(6), 18-28.

Patton, M. Q. (2002). Qualitative Research \& Evaluation Methods. Thousand Oaks: Sage.

Pearlin, L., \& Schooler, C. (1978). The Structure of Coping. Journal of Health and Social Behavior, 19(1), 2-21.

Perakyla, A., \& Ruusuvuori, J. (2011). Analyzing Talk and Text. In N. K. Denzin, \& Y. S. Lincoln, The SAGE Handbook of Qualitative Research (pp. 529-522). Thousand Oaks: Sage.

Perry, V. G., \& Wolburg, J. M. (2011). Aging Gracefully: Emerging Issues for Public Policy and Consumer Welfare. Journal of Consumer Affairs, 45(3), 365-371. doi:10.1111/j.1745-6606.2011.01208.x 
Persad, U., Langdon, P., \& Clarkson, J. (2007). Characterising user capabilities to support inclusive design evaluation. Universal Access in the Information Society, 6, 119-135. doi:10.1007/s10209-007-0083-y

Plummer, J. (2009). Heyday to close after damning report. Retrieved June 20, 2013, from Third Sector: http://www.thirdsector.co.uk/news/879460/

Popper, R., \& Kroll, B. (2003). Food preference and consumption among the elderly. Food Technology, 57(7), 32-40.

Riley, M. W. (1985). Age strata in social systems. In R. H. Binstock, \& E. Shanas (Eds.), Handbook of Aging and the Social Sciences (pp. 369-411). New York: Van Nostrand Reinhold.

Robertson, G. L. (2013). Food Packaging Principles and Practice, 3rd Edition. Brooklyn Sound Pathway: CRC Press.

Rowland, D. T. (1982). The Vulnerability of the Aged in Sydney. Journal of Sociology, 18(2), 229-247. doi:10.1177/144078338201800208

Sara, R. (1990). Packaging as a Retail Marketing Tool. International Journal of Physical Distribution \& Logistics Management, 20(8), 10-21.

Schewe, C. D. (1991). Strategically positioning your way into the ageing marketplace. Business Horizons, 32(1), 19-25.

Schröder-Butterfill, E., \& Marianti, R. (2006). A framework for understanding old-age vulnerabilities. Ageing and Society, 26(1), 9-35. doi:10.1017/S0144686X05004423

Shankar, A., Cherrier, H., \& Canniford, R. (2006). Consumer empowerment: a Foucauldian interpretation. European Journal of Marketing, 40(9-10), 10131030.

Sherman, E., Schiffman, L. G., \& Mathur, A. (2001). The Influence of Gender on the New-Age Elderly's Consumption Orientation. Marketing \& Psychology, 18(10), 1073-1089. 
Silayoi, P., \& Speece, M. (2004). Packaging and purchase decisions. British Food Journal, 106(8), 607-628.

Silayoi, P., \& Speece, M. (2004). Packaging and purchase decisions: An exploratory study on the impact of involvement level and time pressure. British Food Journal, 106(8), 607-628.

Silvers, C. (1997). Smashing old stereotypes of 50-plus America. Journal of Consumer Marketing, 14(4), 303-309.

Simpson, E., O'Connor, J., Livingstone, M., Rae, G., Stewart-Know, B., AndriolloSanchez, M., ... Coudray, C. (2005). Health and lifestyle characteristics of older European adults: the ZENITH study. European Journal of Clinical Nutrition, 59(2), 13-21.

Smith, N. C., \& Cooper-Martin, E. (1997). Ethics and Target Marketing: The Role of Product Harm and Consumer Vulnerability. Journal of Marketing, 61(3), 1-20.

Stephens, N., \& Gwinner, K. P. (1998). Why don't some people complain? A cognitive-emotive process model of consumer complaint behavior. Journal of the Academy of Marketing Science, 26(3), 172-189.

Sudbury, L., \& Simcock, P. (2009a). Understanding Older Consumers through Cognitive Age and the List of Values: A U.K.-Based Perpsective. Psychology \& Marketing, 26(1), 22-38.

Sudbury-Riley, L. (2014). Unwrapping Senior Consumers' Packaging Experiences. Marketing Intelligence and Planning, 32(6), 666-686.

Sudbury-Riley, L., Kohlbacher, F., \& Hofmeister, A. (2012). A cross-cultural analysis of pro-environmental consumer behaviour among seniors. Journal of Marketing Management, 28(3), 290-312.

Szmigin, I., \& Carrigan, M. (2010). The Older Consumers as Innovator: Does Cognitive Age Hold the Key? Journal of Marketing Management, 16(5), 505527.

Thornton, J. E. (2002). Myths of ageing or ageist stereotypes? Educational Gerontology, 28(4), 301-312. 
Turley, D. (1994). The senior market: opportunity or oxymoron? Irish Marketing Review, 7, 16-30.

UK, A. (2012). Food Shopping in Later Life. Retrieved September 24, 2012, from http://www.ageuk.org.uk/Documents/EN-GB/Forprofessionals/Conferences/Final_Food_Shopping_Report.pdf?dtrk=true

UK, A. (2015). Osteoarthritis. Retrieved July 20, 2015, from Age UK: Love later life: http://www.ageuk.org.uk/health-wellbeing/conditions-illnesses/osteoarthritis/

van den Berg-Weitzel, L., \& van de Laar, G. (2001). Relation between culture and communication in packaging design. Journal of Brand Management, 8, 171184.

Visvabharathy, G., \& Rink, D. R. (1985). The Elderly: Still The "Invisible and Forgotten" Market Segment. Journal of the Academy of Marketing Science, 13(4), 81-100.

Voorbij, A. I., \& Steenbekkers, L. P. (2002). The twisting force of aged consumers when opening a jar. Applied Ergonomics, 33(1), 105-109.

Wang, J. J., \& Tian, Q. (2014). Consumer Vulnerability and Marketplace Exclusion: A Case of Rural Migrants and Financial Services in China. Journal of Macromarketing, 34(1), 45-56. doi:10.1177/0276146713508137

Wills, W. J., Meah, A., Dickinson, A. M., \& Short, F. (2015). 'I don't think I ever had food poisoning'. A practice-based approach to understanding foodborne disease that originates in the home. Appetite, 85(1), 118-125. doi:10.1016/j.appet.2014.11.022

Wills, W., Meah, A., Dickinson, A., \& Short, F. (2013). Domestic Kitchen Practices:: Food Standards Agency. Retrieved from http://www.food.gov.uk/sites/default/files/818-11496_KITCHEN_LIFE_FINAL_REPORT_10-07-13.pdf

Winder, B., Ridgway, K., Nelson, A., \& Baldwin, J. (2002). Food and drink packaging: who is complaining and who should be complaining. Applied Ergonomics, 33(5), 433-438. 
Wratten, E. (1995). Conceptualizing urban poverty. Environment and Urbanization, 7(1), 11-38.

Young, Y., Frick, K., \& Phelan, E. A. (2009). Can Successful Aging and Chronic Illness Coexist in the Same Individual? A Multidimensional Concept of Successful Aging. Journal of American Medical Directors Association, 10(2), 87-92.

Yoxall, A., Luxmoore, J., \& Rowson, J. (2008). Size does matter: further studies in hand-pack interaction using computer simulation. Packaging Technology and Science, 21(2), 61-72.

Yoxall, A., Luxmoore, J., Austin, M., Canty, L., Margrave, K. J., Richardson, C. J., . . . Lewis, R. (2007). Getting to grips with packaging: using ethnography and computer simulation to understand hand-pack interaction. Packaging Technology and Science, 20(3), 217-229.

Zohar, D. (1999). When things go wrong: The effect of daily work hassles on effort, exertion and negative mood. Journal of Occupational \& Organizational Psychology, 72(3), 265-283. 


\section{Appendices:}

Table 3: Table Summarising Key Findings

\begin{tabular}{|c|c|c|c|}
\hline $\begin{array}{l}\text { Stage of } \\
\text { packaging } \\
\text { journey }\end{array}$ & $\begin{array}{l}\text { Packaging } \\
\text { function }\end{array}$ & Theme & Illustrative quote/s \\
\hline \multirow{4}{*}{ Point of sale } & \multirow[b]{2}{*}{ Communication } & Legibility of labels & $\begin{array}{l}\text { "When l'm in the shop I can't read the labels. I look for the best-before date but can't distinguish it } \\
\text { because all the writing it's so small" - June (61). }\end{array}$ \\
\hline & & $\begin{array}{l}\text { Transparent packaging/ } \\
\text { consumer mistrust }\end{array}$ & $\begin{array}{l}\text { "On most packaging is seems like the pictures and logos are the things the companies care most about, } \\
\text { not about the way the product works. Half the time the thing you're buying doesn't look like the picture } \\
\text { anyway" - Philippa (73). }\end{array}$ \\
\hline & $\begin{array}{l}\text { Apportionment } \\
\text { (product } \\
\text { size/weight) }\end{array}$ & $\begin{array}{l}\text { Retrieving cumbersome } \\
\text { products }\end{array}$ & $\begin{array}{l}\text { "When l'm in the shop I prefer to use a basket. Leaning on the trolley does things to my balance, and I } \\
\text { only ever get a few bits anyway. But when you're buying big heavy things it's a struggle using the basket" } \\
\text { - Bill (86). }\end{array}$ \\
\hline & $\begin{array}{l}\text { Containment/recy } \\
\text { clability }\end{array}$ & $\begin{array}{l}\text { Environmental } \\
\text { concerns }\end{array}$ & $\begin{array}{l}\text { "I'll always look for the smaller tin. It suits us better and you know it's less harmful to the environment" - } \\
\text { Michael (59). }\end{array}$ \\
\hline $\begin{array}{l}\text { Transporting the } \\
\text { product home }\end{array}$ & $\begin{array}{l}\text { Apportionment } \\
\text { (product } \\
\text { size/weight) }\end{array}$ & Dependence on others & $\begin{array}{l}\text { "When my son is around I can go with him to get the heavy shopping because he's got a car. When he } \\
\text { isn't around I have to wait for a few weeks before I buy big stuff like washing powder" - Yvonne (81). }\end{array}$ \\
\hline
\end{tabular}




\begin{tabular}{|c|c|c|c|}
\hline & & $\begin{array}{l}\text { Changing shopping } \\
\text { habits }\end{array}$ & $\begin{array}{l}\text { "I'm beginning to think sometimes, it feels like my shopping is getting heavier pushing it around, maybe I } \\
\text { should do online shopping" - Sue (61). }\end{array}$ \\
\hline Home storage & $\begin{array}{l}\text { Apportionment } \\
\text { (product } \\
\text { size/weight) }\end{array}$ & $\begin{array}{l}\text { Storing cumbersome } \\
\text { products }\end{array}$ & $\begin{array}{l}\text { "I try and avoid using the top shelves in my cupboard. It's too much hard work getting stuff in and out of } \\
\text { them. It's like how I struggle with opening and closing the window in my kitchen because it's so high up"- } \\
\text { Maude (82). }\end{array}$ \\
\hline \multirow{3}{*}{ Opening } & \multirow{3}{*}{ Openability } & Gross motor skills & $\begin{array}{l}\text { "The number one thing I have problems with is jars of pasta sauce. I've found that if you stab the lid firmly } \\
\text { with a very sharp knife that often breaks the seal. It's a bit of a concern because it's so dangerous"- June } \\
\text { (61). } \\
\text { "I'm not happy using them [scissors], but I have to, otherwise I wouldn't physically be able to get to the } \\
\text { product" (Bill, 86). }\end{array}$ \\
\hline & & Fine motor skills & $\begin{array}{l}\text { "The cheese from Iceland is skin tight. You can't get a good grip on it which makes it very difficult to open. } \\
\text { It's like trying to skin a rabbit" - Yvonne (81). }\end{array}$ \\
\hline & & Overcoming difficulties & $\begin{array}{l}\text { "I haven't been able to open jars properly for a long time. This contraption is a work of art - I couldn't be } \\
\text { without it" - Elizabeth (72). } \\
\text { "You need an implement for everything. Even with the help of tools it's still hard" - June (61). } \\
\text { "My brother influenced me a lot. If he had a problem that he couldn't find a tool to fix, then he'd make his } \\
\text { own, so that's what I do [with packaging]. If I still can't open it after that, I don't know what to do..." - } \\
\text { Maude (82). }\end{array}$ \\
\hline $\begin{array}{l}\text { Serving the } \\
\text { product for } \\
\text { consumption }\end{array}$ & Apportionment & $\begin{array}{l}\text { Inappropriate portion } \\
\text { sizes (biological } \\
\text { ageing) }\end{array}$ & $\begin{array}{l}\text { "I shan't get them, four [sausages] is too much for me, particularly when you've got to eat them two days } \\
\text { after opening" - Bill (86). } \\
\text { "For fresh food it's the worst because you can't freeze it. I can't get through two [punnets] of oranges on } \\
\text { my own" - Carol (77). }\end{array}$ \\
\hline
\end{tabular}




\begin{tabular}{|c|c|c|c|}
\hline & & $\begin{array}{l}\text { Inappropriate portion } \\
\text { sizes (social ageing) }\end{array}$ & $\begin{array}{l}\text { "As my children have grown up and left home, my shopping basket is now smaller. I don't need to buy } \\
\text { giant sized packets of things. Especially things like breakfast cereals that go off" - Sue (61). } \\
\text { "When we grew up it was just after the war, so there was still rationing. Our parents had to buy what they } \\
\text { could and make it last, not have it for one meal and then throw it away [like people do now" - Philippa } \\
\text { (73). }\end{array}$ \\
\hline & Communication & Legibility of labels & $\begin{array}{l}\text { "The fonts on so many things are rubbish. Silly little letters. I've got about } 20 \text { pairs of cheap Primark } \\
\text { spectacles around the house, mainly for reading labels" - June (61). }\end{array}$ \\
\hline \multirow{2}{*}{$\begin{array}{l}\text { Reclosing or } \\
\text { putting away }\end{array}$} & \multirow{2}{*}{ Reclosability } & $\begin{array}{l}\text { Preference for re- } \\
\text { sealable packaging }\end{array}$ & $\begin{array}{l}\text { "I usually buy } 3 \text { packets of crisps a year. I eat them very slowly, so I'll always buy one of the small pipes of } \\
\text { Pringles. They're the only ones I can eat at my own pace without them going off" - Maude (82). }\end{array}$ \\
\hline & & $\begin{array}{l}\text { Ineffective solutions } \\
\text { (self-blame) }\end{array}$ & "It's probably me, but I always seem to have trouble with it" - Bill (86). \\
\hline \multirow[b]{2}{*}{ Disposal } & $\begin{array}{l}\text { Containment/recy } \\
\text { clability }\end{array}$ & $\begin{array}{l}\text { Environmental } \\
\text { concerns }\end{array}$ & $\begin{array}{l}\text { "Things have gotten a little bit better in the past few years, but the amount of packaging has just gotten } \\
\text { ridiculous. I believe the companies who genuinely care about the environment are still in the great } \\
\text { minority" - Jim (63) }\end{array}$ \\
\hline & $\begin{array}{l}\text { Containment/reus } \\
\text { ability }\end{array}$ & Second-life packaging & $\begin{array}{l}\text { "I reuse all sorts of stuff; jars, my Jean-Paul Gaultier perfume tins. They're all useful for storing different } \\
\text { things"- June (61) } \\
\text { "You don't mind paying a price premium for a bottle of water with a sports cap as it means you can reuse } \\
\text { it" - Michael (59). }\end{array}$ \\
\hline
\end{tabular}

